\title{
Microgravity Affects Thyroid Cancer Cells during the TEXUS-53 Mission Stronger than Hypergravity
}

\author{
Sascha Kopp ${ }^{1}$, Marcus Krüger ${ }^{1}{ }^{\circledR}$, Johann Bauer ${ }^{2}$, Markus Wehland ${ }^{1}$, Thomas J. Corydon ${ }^{3,4}$, \\ Jayashree Sahana $^{3}$, Mohamed Zakaria Nassef ${ }^{1}$, Daniela Melnik ${ }^{1}$, Thomas J. Bauer ${ }^{1}$, \\ Herbert Schulz ${ }^{5}$, Andreas Schütte ${ }^{6}$, Burkhard Schmitz ${ }^{6}$, Hergen Oltmann ${ }^{6}$, Stefan Feldmann ${ }^{6}$, \\ Manfred Infanger ${ }^{1}$ and Daniela Grimm ${ }^{1,3,7, *}$ \\ 1 Clinic for Plastic, Aesthetic and Hand Surgery, Otto von Guericke University Magdeburg, Leipziger Str. 44, \\ D-39120 Magdeburg, Germany; sascha.kopp@med.ovgu.de (S.K.); marcus.krueger@med.ovgu.de (M.K.); \\ markus.wehland@med.ovgu.de (M.W.); mohamed.nassef@med.ovgu.de (M.Z.N.); \\ daniela.melnik@med.ovgu.de (D.M.); thomas.bauer@med.ovgu.de (T.J.B.); \\ manfred.infanger@med.ovgu.de (M.I.) \\ 2 Max Planck Institute of Biochemistry, D-82152 Martinsried, Germany; jbauer@biochem.mpg.de \\ 3 Department of Biomedicine, Aarhus University, Wilhelm Meyers Allé 4, DK-8000 Aarhus C, Denmark; \\ corydon@biomed.au.dk (T.J.C.); jaysaha@biomed.au.dk (J.S.) \\ 4 Department of Ophthalmology, Aarhus University Hospital, Aarhus, 8000 Aarhus C, Denmark \\ 5 Cologne Center for Genomics, University of Cologne, D-50931 Cologne, Germany; \\ herbert.schulz@uni-koeln.de \\ 6 Airbus Defence and Space GmbH, Airbus-Allee 1, D-28199 Bremen, Germany; \\ andreas.schuette@airbus.com (A.S.); burkhard.schmitz@airbus.com (B.S.); \\ hergen.oltmann@airbus.com (H.O.); stefan.feldmann@airbus.com (S.F.) \\ 7 Gravitational Biology and Translational Regenerative Medicine, Faculty of Medicine and Mechanical \\ Engineering, Otto-von-Guericke-University Magdeburg, D-39120 Magdeburg, Germany \\ * Correspondence: dgg@biomed.au.dk; Tel.: +45-871-67693
}

Received: 15 November 2018; Accepted: 9 December 2018; Published: 12 December 2018

check for updates

\begin{abstract}
Thyroid cancer is the most abundant tumor of the endocrine organs. Poorly differentiated thyroid cancer is still difficult to treat. Human cells exposed to long-term real (r-) and simulated $(\mathrm{s}-)$ microgravity $(\mu g)$ revealed morphological alterations and changes in the expression profile of genes involved in several biological processes. The objective of this study was to examine the effects of short-term $\mu g$ on poorly differentiated follicular thyroid cancer cells (FTC-133 cell line) resulting from $6 \mathrm{~min}$ of exposure to $\mu \mathrm{g}$ on a sounding rocket flight. As sounding rocket flights consist of several flight phases with different acceleration forces, rigorous control experiments are mandatory. Hypergravity (hyper-g) experiments were performed at $18 g$ on a centrifuge in simulation of the rocket launch and s- $\mu g$ was simulated by a random positioning machine (RPM). qPCR analyses of selected genes revealed no remarkable expression changes in controls as well as in hyper- $g$ samples taken at the end of the first minute of launch. Using a centrifuge initiating $18 \mathrm{~g}$ for $1 \mathrm{~min}$, however, presented moderate gene expression changes, which were significant for COL1A1, VCL, CFL1, PTK2, IL6, CXCL8 and MMP14. We also identified a network of mutual interactions of the investigated genes and proteins by employing in-silico analyses. Lastly, $\mu g$-samples indicated that microgravity is a stronger regulator of gene expression than hyper- $g$.
\end{abstract}

Keywords: Microgravity; hypergravity; random positioning machine; thyroid cancer; sounding rocket; cytoskeleton; focal adhesion; extracellular matrix 


\section{Introduction}

Thyroid cancer (TC) is one of the most abundant neoplasms of the endocrine organs [1]. Thyroid carcinomas are malignant tumors of the thyroid gland and are classified into differentiated TC (papillary TC, follicular TC and Hürthle cell cancer), medullary TC; and anaplastic TC. The American Cancer Society recently estimated that in the US in 2018 about 2,060 persons died from TC [1].

Thyroid cells as well as differentiated TC cells are capable of taking up iodine [2]. When radioactive iodine (RAI; ${ }^{131} \mathrm{I}$ ) is given, it concentrates in the thyroid. The radiation will destroy the thyroid gland and any other benign and malignant thyroid cells. RAI-treatment is used to ablate any thyroid tissue in the organism. Unfortunately, undifferentiated TC cells lost the ability to take up iodine which increases the need to find new therapeutically valuable treatments [3], for example by targeting tumor angiogenesis $[2,4]$.

Microgravity $(\mu g)$ offers a very special culture environment for cells enabling three-dimensional (3D) growth. This environment is suitable for tissue engineering purposes, while exposing cells to an unknown stress and thereby forcing them to react and adapt to this new condition [5-7].

Normal and benign thyroid cells have been examined after cultivation on a random positioning machine (RPM) at various time-points [8-10]. The results suggest that RPM-exposure changed differentiation and growth behavior of poorly differentiated malignant FTC-133 cells after long-term RPM-exposure [8]. Comparable results were obtained from the Simbox/Shenzhou-8 mission, when FTC-133 cells were cultured on an unmanned spacecraft for 10 days [11].

Furthermore, the cytoskeleton underwent changes in structure and organization by exposure to $\mu g$. This was demonstrated during parabolic flights as well as a TEXUS (TX) sounding rocket mission, where a novel live-cell imaging approach using the FLUMIAS microscope revealed the occurrence of "holes" in the F-actin-network and in lamellipodia- and filopodia-like structures [12]. According to the tensegrity model, meaning that cells gain their structure through a pervasive tensional force, the cytoskeleton might play an important role in the mechano- and gravisensing process of human cells $[13,14]$. It is proposed that the cytoskeleton acts as a mediator and conductor of signals from the extracellular space into the nucleus due to it being hardwired to specific cell surface proteins, such as integrins, which are involved in focal adhesion formation and cell-cell interaction [15,16], as well as to cytoplasmic transduction molecules [13]. Proteins involved in the linkage of the cytoskeleton to membrane proteins and the ECM are most prominently talin, vinculin or the ERM proteins [17-19].

To determine the impact of $r-\mu g$ on the cells after the 1-min long hyper- $g$ phase during launch-, FTC-133 cells were exposed to 6 min of r- $\mu g$ during the TEXUS-(TX) 53 mission [20] and in parallel to $1 \mathrm{~min}$ of $18 \mathrm{~g}$ on a centrifuge (see Figure 1 of [20]). In addition, we compared the effects of the short-term $r-\mu g$ with a 6-min cultivation on the RPM (s- $\mu g)$, focusing on extracellular matrix (ECM) proteins, the cytoskeleton, cell adhesion, focal adhesion and cytokines.

The expression of genes and the accumulation of proteins, which were known to be highly sensitive to altered gravity conditions were analyzed. Furthermore, we have conducted an in-silico analysis including data from the literature to identify possible mutual interaction networks between the analyzed proteins, as successfully practiced earlier [21,22]. 


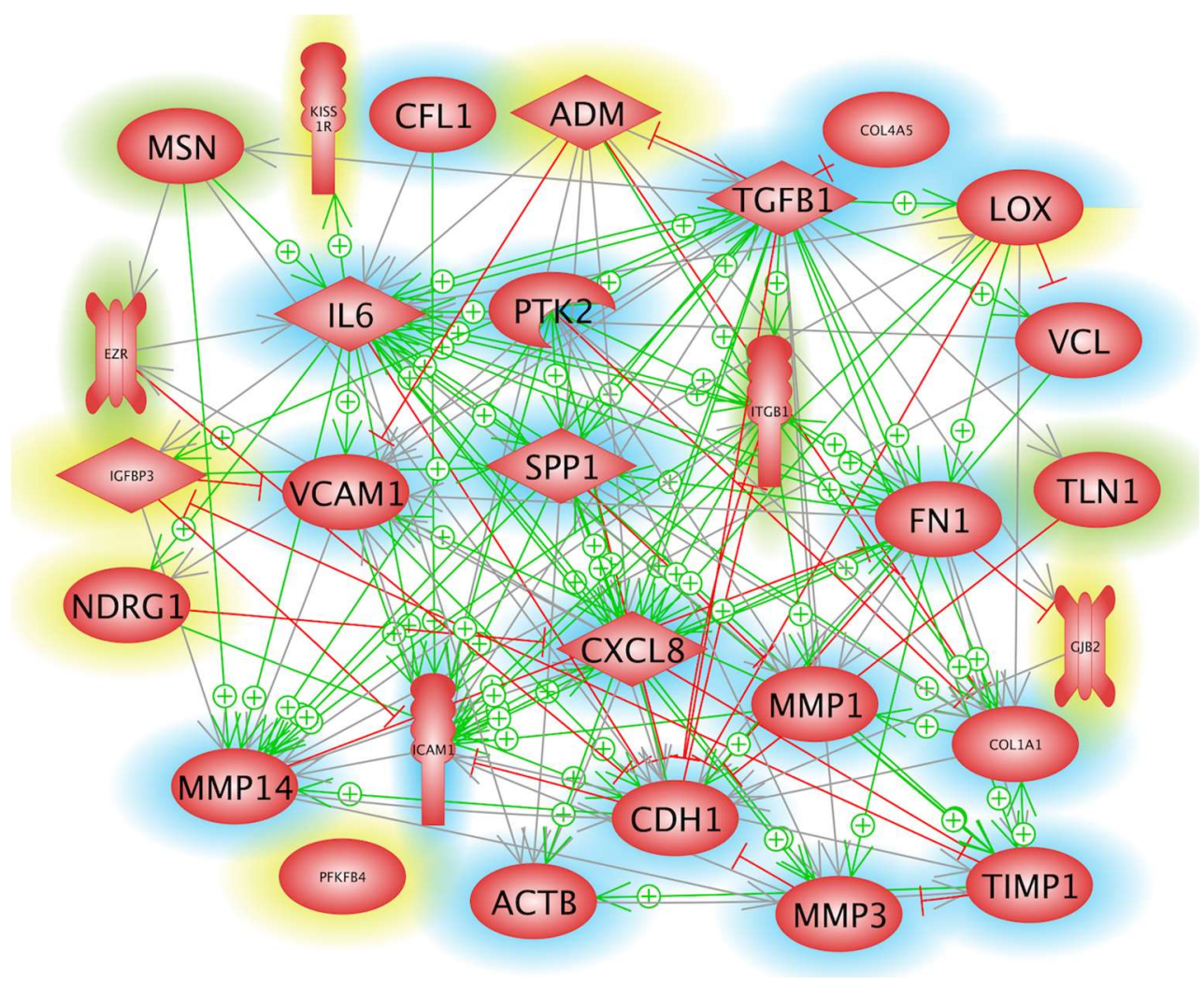

Figure 1. Network of interaction and mutual influence of the identified entities on a gene expression level. The genes, whose icons are marked with a green or blue rim have been found in recent studies referenced or mentioned in the preceding paper [20], respectively. The genes displayed with yellow icons attracted our attention when the two $\mu g$-samples were investigated by gene array analysis, although the result lacked significance due to the fact of only two samples being available per experiments. Green arrows with a plus sign indicate expression or enhanced expression of a gene to which an arrow points to and red lines with a terminal crossbar show suppression or reduced expression of the gene near the crossbar. Grey arrows point to interaction with unknown effects as of now.

\section{Results}

After the samples' return to the laboratory, quantitative real-time PCR (qPCR) and pathway analyses were performed. The studies were done on the samples collected during the TX53 mission as described in [20] as well as on samples exposed to $18 \mathrm{~g}$ (worst case) hyper-g on a centrifuge, or cultured for 6-min of s- $\mu$ g exposure on an RPM. We focused on the F-actin cytoskeleton, the ECM, focal adhesion, cell adhesion molecules, and cytokines. Various genes belonging to these groups and recently found to be differentially expressed during long-term spaceflights and RPM-experiments (Table 1) were investigated.

The genes listed in Table 1 were complemented with a number of additional genes known to be involved in cell-cell and cell-substrate adhesion. The in-silico evaluation of the selected genes revealed a self-contained network. These genes, indicated by a green or blue rim, form a network of mutual influence (Figure 1, icons with red rim), with TGFB1, ITGB1, SPP1, IL-6, IL8, FN1, COL1A1, CDH1, and MMP14 being nodal points of this network. Additionally, many arrows start at TGFB1, LOX and PTK2, meaning that these entities are effectors in the system. Interestingly, the 6 genes marked with a yellow rim fit rather well into the network. These genes caught our attention during a preliminary evaluation of the microarray analysis of the two $\mu g$-samples available, because they were at least 1.7-fold enhanced in comparison to the controls. 
Table 1. Summary of previously found regulations in selected molecular targets due to gravitational alterations. $\uparrow$ indicates upregulation; $\downarrow$ indicates downregulation; double arrow indicates significant alterations; $\rightarrow$ indicates no regulation, blank was not examined.

\begin{tabular}{|c|c|c|c|c|c|c|c|}
\hline Cell Line & \multicolumn{2}{|c|}{$g$-Condition } & FN1 & COL1A1 & COL4A5 & SPP1 & Reference \\
\hline \multirow{6}{*}{ FTC-133 } & Space & 10 days & & & & $\downarrow$ & [11] \\
\hline & \multirow{3}{*}{ RPM } & 1 day & & & & $\mathrm{AD} \uparrow \uparrow \mathrm{MCS} \uparrow$ & [23] \\
\hline & & 7 days & & $\downarrow$ & & $\uparrow \uparrow$ & [8] \\
\hline & & 14 days & & $\downarrow$ & & $\uparrow \uparrow$ & [8] \\
\hline & PFC & $31 \mathrm{P}$ & & & & $\mathrm{WT} \uparrow \uparrow$ & [11] \\
\hline & hyper-g & $2 \mathrm{~h}$ & & & & & [11] \\
\hline \multirow{5}{*}{$\begin{array}{c}\text { Nthy-ori } \\
3-1\end{array}$} & \multirow{5}{*}{ RPM } & $4 \mathrm{~h}$ & $\mathrm{AD} \uparrow$ & & & & [9] \\
\hline & & 1 day & $\mathrm{AD} \uparrow \mathrm{MCS} \downarrow$ & & & & [9] \\
\hline & & 3 days & $\mathrm{AD} \rightarrow \mathrm{MCS} \rightarrow$ & & & & [9] \\
\hline & & 7 days & & $\uparrow \uparrow$ & & & [8] \\
\hline & & 14 days & & $\uparrow \uparrow$ & & $\uparrow \uparrow$ & [8] \\
\hline Cell line & \multicolumn{2}{|c|}{$g$-Condition } & ICAM1 & VCAM1 & IL6 & CXCL8 & Reference \\
\hline \multirow{6}{*}{ FTC-133 } & Space & 10 days & & & $\downarrow$ & $\downarrow$ & [11] \\
\hline & \multirow{3}{*}{ RPM } & 1 day & & & $\mathrm{AD} \uparrow \uparrow \mathrm{MCS} \downarrow \downarrow$ & $\mathrm{AD} \uparrow \uparrow \mathrm{MCS} \uparrow$ & [23] \\
\hline & & 7 days & & & १个 & $\mathrm{AD} \uparrow \uparrow \mathrm{MCS} \downarrow \downarrow$ & [8] \\
\hline & & 14 days & & & $\uparrow \uparrow$ & $\mathrm{AD} \uparrow \uparrow \mathrm{MCS} \rightarrow$ & [8] \\
\hline & PFC & $31 \mathrm{P}$ & & & $\mathrm{WT} \uparrow \uparrow$ & $\mathrm{WT} \uparrow \uparrow$ & [11] \\
\hline & hyper-g & $2 \mathrm{~h}$ & & & & & [11] \\
\hline \multirow{5}{*}{$\begin{array}{c}\text { Nthy-ori } \\
3-1\end{array}$} & \multirow{5}{*}{ RPM } & $4 \mathrm{~h}$ & & & & & [9] \\
\hline & & 1 day & & & & & [9] \\
\hline & & 3 days & & & & & [9] \\
\hline & & 7 days & & & $\uparrow \uparrow$ & $\mathrm{AD} \uparrow \uparrow \mathrm{MCS} \downarrow \downarrow$ & [8] \\
\hline & & 14 days & & & $\uparrow \uparrow$ & $\mathrm{AD} \uparrow \uparrow \mathrm{MCS} \uparrow \uparrow$ & [8] \\
\hline
\end{tabular}

Regarding the products of these genes (Figure 2), three groups can be distinguished: There are extracellular proteins, membrane proteins and intracellular proteins. As indicated above, the proteins whose icons are marked with a green or blue rim, are gene products found in recent studies referenced or mentioned in the preceding paper [20], respectively. On the protein level, however, the most important nodal points are fibronectin and integrin $\beta$ 1. Intracellularly, they are connected to VCL, MSN and ACTB, which are involved in forwarding signals, generated by cells' binding to the ECM, towards the nucleus.

\subsection{Impact of Microgravity on the Regulation of Genes Whose Products Act Extracellularly}

Immunofluorescence staining (IFS) showed that the ECM protein fibronectin was redistributed in RPM-samples compared to control cells (Figure 3A,B). The FN1 gene expression was not significantly altered (Figure 3C). In addition, fibronectin expression did not change in FTC-133 cells exposed to the RPM for 6 min (Figure 3D). COL1A1 mRNA, however, was significantly upregulated in hyper-g samples compared with corresponding controls (Figure 3E), whereas the COL4A5 mRNA remained stable in all groups (Figure $3 \mathrm{~F}$ ). The expression of the structural protein collagen IV was not significantly changed by short-term $\mu g$ as compared to the corresponding control (Figure 3G). 


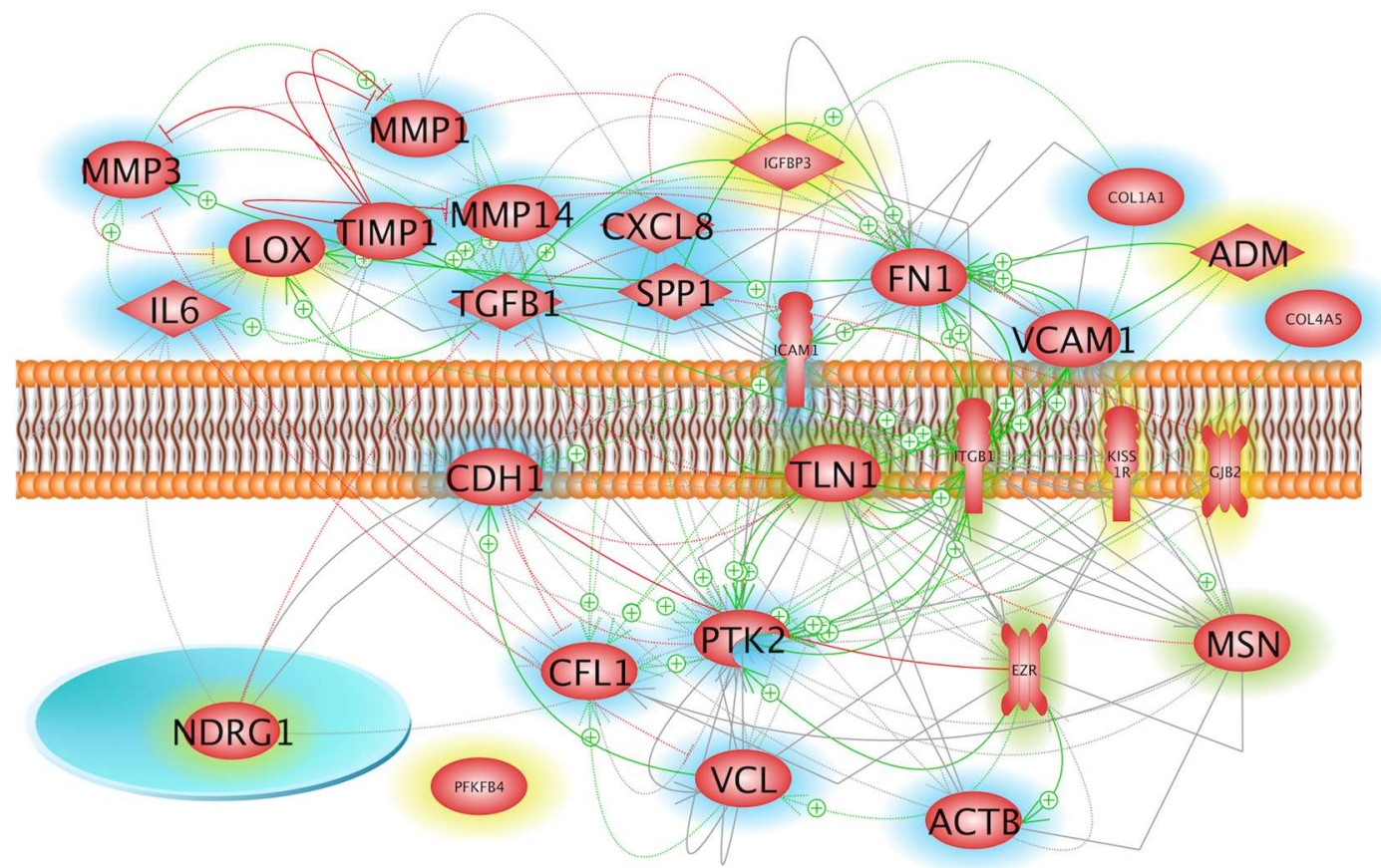

Figure 2. Localization and interaction of the products of genes mentioned above. The icons of genes products found in recent studies referenced or mentioned in the preceding paper [20], are marked with a green or blue rim, respectively. The genes products marked by yellow icons attracted our attention when the $\mu g$ samples (2) were evaluated by gene array analysis, although the results lacked significance due to the fact that only two samples per experiments were available. Green arrows with plus sign indicate stimulation and red lines with terminal crossbar show inhibition. Grey arrows indicate direct (solid line) or indirect (dashed line) interaction with unknown effect. Grey lines show protein-protein complex formation.

Moreover, we studied the ECM protein and cell adhesion molecule osteopontin. The secreted phosphoprotein 1 (SPP1) gene expression, determined in post-flight and hyper-g samples was slightly, but not significantly elevated (Figure 3H). RPM-exposure of the FTC-133 cells did not induce significant changes in the amount of protein in both groups (Figure 3I). qPCR of TGFB1 mirrored these findings (Figure 3J).

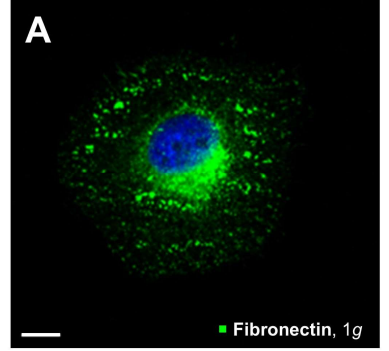

E

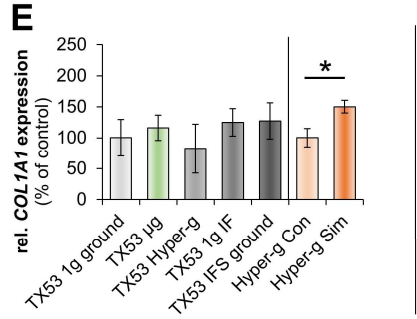

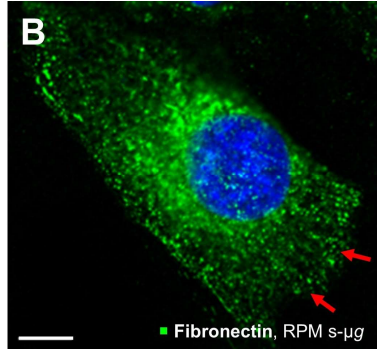

F

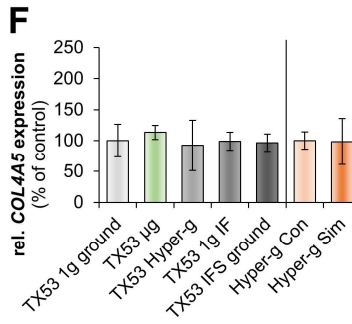

Figure 3. Cont.
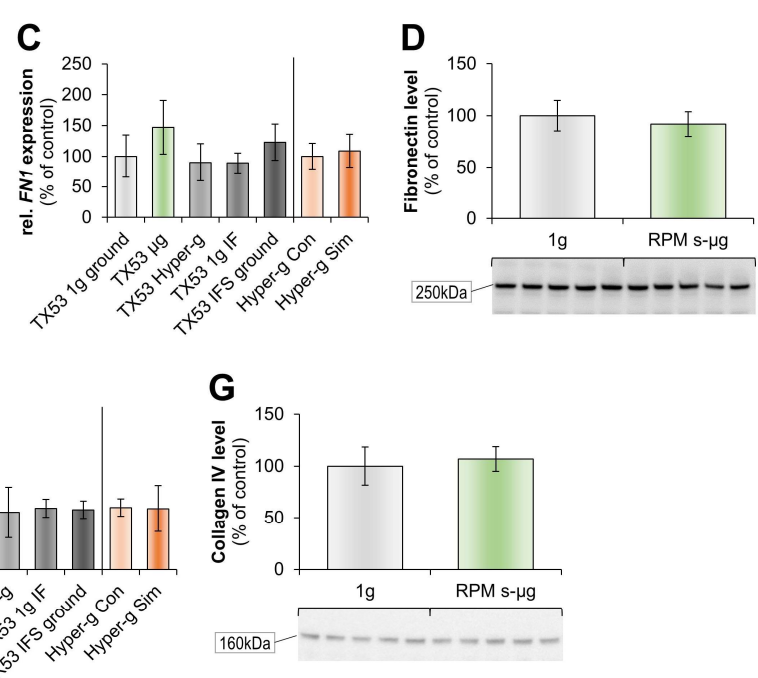

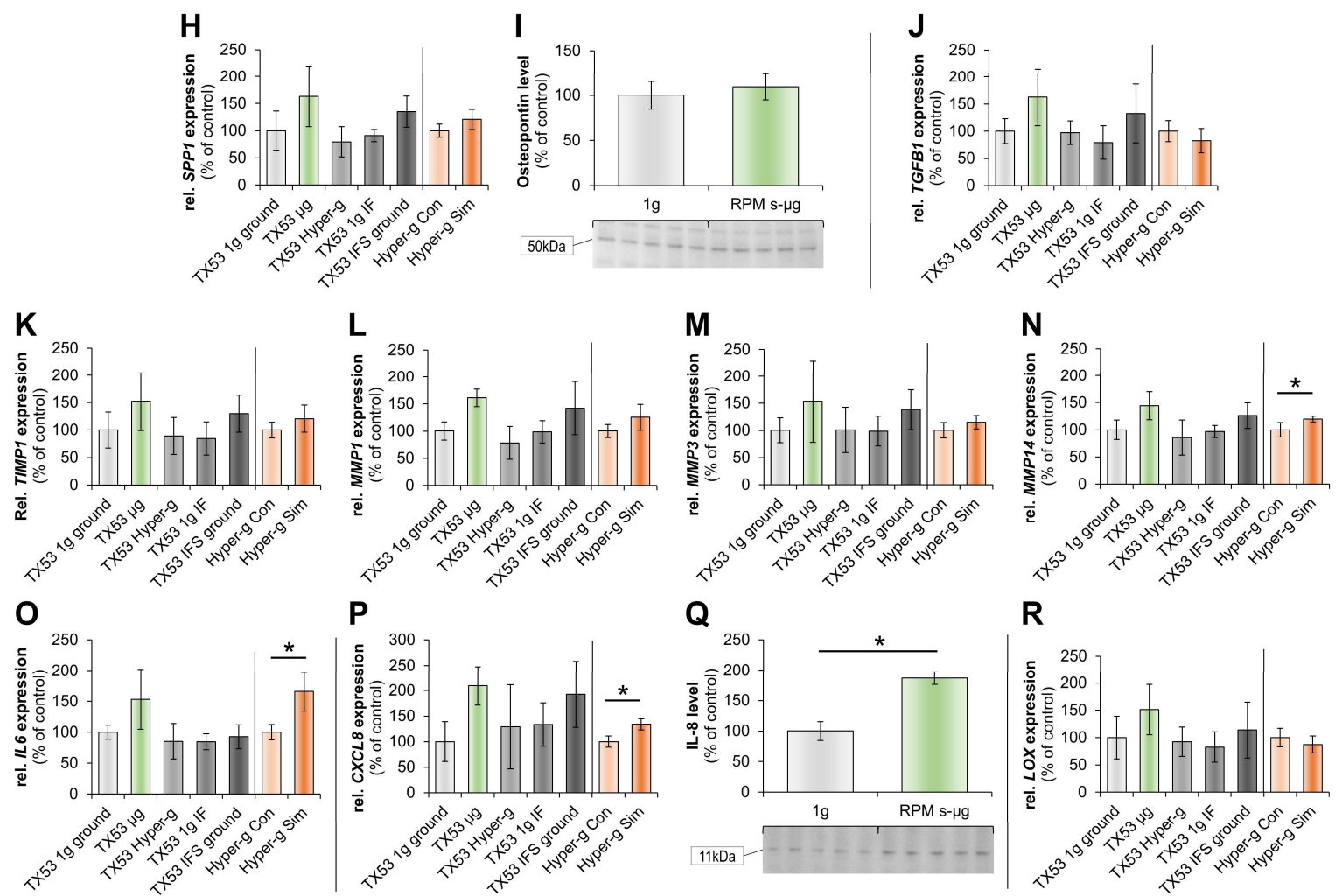

Figure 3. IFS of fibronectin (green) and nucleus (blue) (A,B); scale bar $10 \mu \mathrm{m}$; red arrow redistributed fibronectin, qPCR analyses of FN1 (C), Col1A1 (E), Col4A5 (F), SPP1 (H), TGB1 (J), TIMP1 (K), MMP1 (L), MMP3 (M), MMP14 (N), IL-6 (O), CXCL8 (P) and LOX (R), and WB of fibronectin (D), collagen IV (G), osteopontin (I), and IL-8 (Q). "TX53" indicates samples collected from the sounding rocket mission, whereas "Hyper-g" presents data from a parallel experiment simulating the worst case-possible launch acceleration. IF: in-flight; Con: control; Sim: simulated; RPM: random positioning machine; $6 \mathrm{~min} \mathrm{s- \mu g;}$ * $p<0.05$ vs. $1 g$.

Finally, we determined the gene expression patterns of tissue inhibitor of metalloproteinase 1 (TIMP1) and matrix metalloproteinases MMP1, MMP3 and MMP14 (Figure 3K-N). TIMP1, MMP1, and MMP3 genes were slightly elevated in $\mathrm{r}-\mu \mathrm{g}$, whereas the MMP14 mRNA was elevated in $\mathrm{r}-\mu \mathrm{g}$ and significantly elevated in hyper- $g$ samples (Figure $3 \mathrm{~N}$ ).

Earlier studies investigating the impact of $\mu g$ on human cells and the synthesis and secretion of the two cytokines interleukin-6 (IL-6) and interleukin-8 (IL-8 or synonymous CXC-motif-chemokine 8, (CXCL8)) have shown their involvement in 3D spheroid formation [24]. The release and expression of both cytokines was altered in space in FTC-133 cells [24]. Here we show that both, the IL6 and CXCL8 mRNA are elevated in the $r-\mu g$ and $18 g$ centrifugation groups compared to controls (Figure 3O,P), while the IL8 protein expression was significantly enhanced during 6 min on the RPM (Figure 3Q). The LOX mRNA expression was elevated in $\mathrm{r}$ - $\mu g$ samples, but remained unaltered in all other groups (Figure 3R).

\subsection{Influence of Microgravity on Genes of Membrane Proteins and Their Accumulation}

The F-actin staining of RPM-exposed FTC-133 cells revealed stress fibers (yellow arrows) and lamellipodia together with filopodia (blue arrows) compared to controls (Figure 4A,B). In addition, F-actin accumulated at the cell membrane (Figure 4B). The beta-actin protein was reduced in RPM-samples compared to static $1 g$-controls (Figure 4C). 

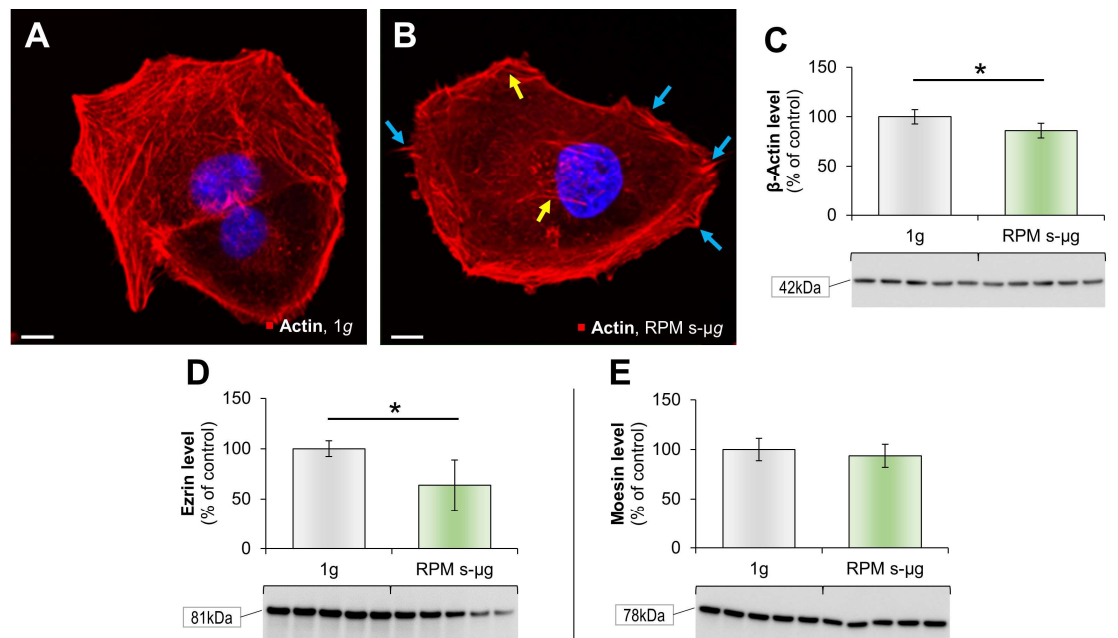

E
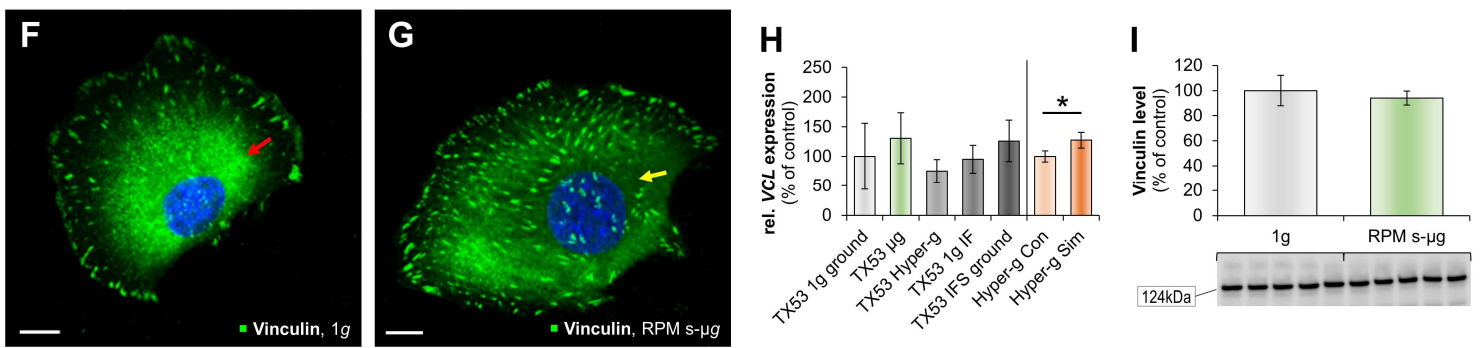

\section{K}
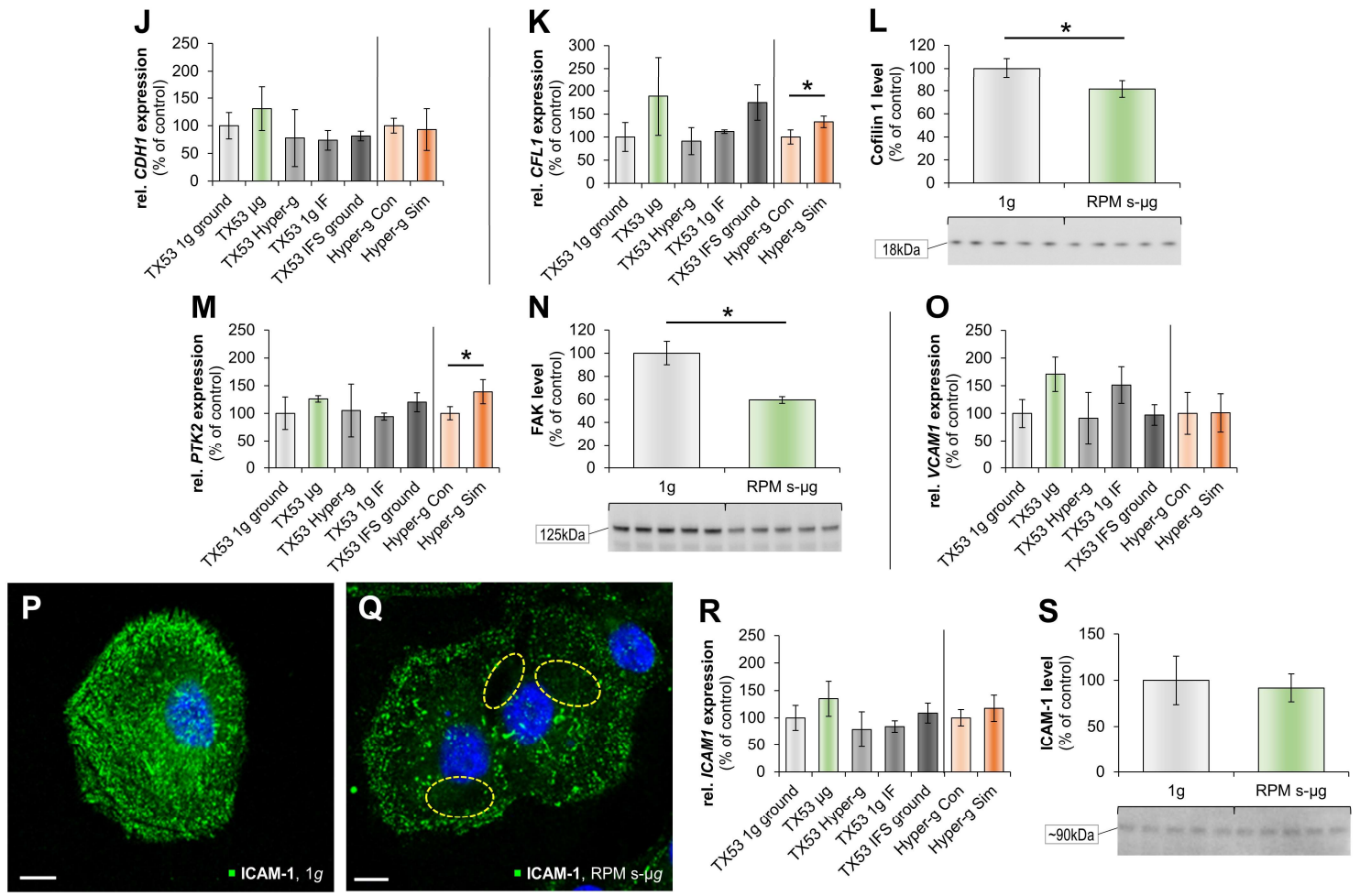

Figure 4. Histological staining of F-actin (red) and the nucleaus (blue) (A,B); yellow arrows: stress fibers and blue arrows: filopodia and lamellipodia; IFS of vinculin (green) and nucleus (blue) (F,G); red arrow: compact vinculin in $1 g$ around the nucleus and yellow arrow: redistributed vinculin in RPM-samples; ICAM-1 (green) and nucleus (blue); yellow circles: areas with no ICAM1-positivity in RPM-samples (P,Q); scale bar $10 \mu \mathrm{m}$. qPCR analyses of $V C L(\mathbf{H})$, CDH1 (J), CFL1 (K), PTK2 (M), VCAM1 (O), ICAM1 (R), and WB of ACTB (C), ezrin (D), moesin (E), VCL (I), cofilin (L), FAK (N), ICAM1 (S). "TX53" indicates samples collected during the sounding rocket mission, whereas "Hyper-g" presents data from a parallel experiment aiming on the worst case-possible launch acceleration. IF: in-flight; Con: control; Sim: simulated; RPM: random positioning machine; $6 \mathrm{~min} \mathrm{s- \mu g;} p<0.05$ vs. $1 g$, scale bars: $10 \mu \mathrm{m}$. 
In a further step, we found a reduction for the protein ezrin in s- $\mu g$ (Figure $4 \mathrm{D})$, but no significant changes for moesin (Figure 4E) [20].

Immunofluorescence staining of vinculin showed a normal distribution of this cytoskeletal protein, present in adherence-type cell junctions in the FTC-133 cells, at $1 g$ (Figure 4F). A clear disorganization of vinculin was visible in RPM-exposed FTC-133 cells (Figure 4G). VCL was not changed in the flight samples, but significantly elevated by $18 g$ centrifugation (Figure $4 \mathrm{H}$ ). Vinculin expression was not changed after RPM-exposure compared to $1 g$ (Figure 4I). Vinculin regulates the E-cadherin expression and is involved in mechanosensing by the E-cadherin complex. Therefore, we evaluated the CDH1 mRNA expression, which was not altered in any of the samples (Figure $4 \mathrm{~J}$ ).

Vinculin and E-cadherin are known to be involved in cell morphology and locomotion. Another F-actin-binding protein is cofilin. The CFL1 gene was elevated in $\mathrm{r}-\mu g$, and significantly enhanced in hyper- $g$ samples (Figure $4 \mathrm{~K}$ ), indicating its role in the dynamics and organization of the F-actin cytoskeletal network. Western blot analysis of cofilin revealed a significant reduction in the RPM sample (Figure 4L). Focal adhesions are multiprotein structures connecting the ECM and the cytoskeleton.

Focal adhesion kinase 1 (FAK1 or protein tyrosine kinase 2 (PTK2)) is important for cell migration and its inhibition decreases mobility and metastasis. The PTK2 mRNA was not altered in the TEXUS samples, but elevated by $18 g$ centrifugation compared to the corresponding control (Figure $4 \mathrm{M}$ ). The FAK1 protein content was significantly reduced in RPM samples (Figure 4N)

Finally, we measured the gene expression of the cell adhesion molecules vascular cell adhesion molecule 1 (VCAM1) (Figure 4O) and intercellular adhesion molecule 1 (ICAM1) (Figure 4R). Both proteins were upregulated in $r-\mu g$, but not significantly changed in hyper-g (Figure $4 \mathrm{O}, \mathrm{R}$ ). ICAM-IFS visualized changes between the two groups ( $1 g$ vs. RPM-exposure) (Figure 4P,Q). In RPM-samples ICAM1 IFS revealed holes and a lower density of ICAM-positive areas (Figure 4Q), but the ICAM1 protein concentration remained stable during 6 min on the RPM (Figure 4S).

Due to a kink in a fixative tubing one culture chamber was not filled with fixative, meaning that one $\mu g$-chamber was not fixed with RNAlater at the end of the 6-min $\mu g$-phase [20]. Therefore, the cells harvested from the residual two $\mu g$-samples did not allow a significant microarray gene analysis. In order to obtain preliminary hints on possible gene regulation within the six early minutes of $\mu g$, we compared the result of microarray analysis of the three $1 g$-samples with the average values of two measurements of the $\mu g$-samples. Of the 27,600 genes analyzed, eight genes appeared to be down-regulated, while seven seemed to be upregulated. While no further indication was found for the relevance of the apparent down-regulation, the comparison pointed to the possibility that $L O X, A D M$, IGFBP3, NDRG1, KISS1R, GJB2, PFKFB4 genes could at least be upregulated1.7-fold after 6 min of $\mu g$. The speculation is supported by the result that besides PFKFB4 these genes and their products are members of the networks shown in Figures 1 and 2. In addition, several earlier studies have shown that all these genes or their products are gravisensitive and are downregulated during a prolonged stay in weightlessness [11,24-26].

\section{Discussion}

The exposure of thyroid cells to $\mathrm{r}$ - and s- $\mu g$ led to promising results in regard to re-differentiation of TC cells $[8,11,23,27-29]$. Especially a 10-day long-term sojourn in $\mu g$ during an unmanned space mission revealed gene expression changes suggesting a re-differentiation of the TC cells compared to their ground controls [11]. In this study, we could advance this theory and learned that up- and downregulation of a given gene may be a time-dependent process.

\subsection{Impact of Microgravity on the Cytoskeleton}

It is still unknown how cells are able to sense $\mu g$. An interesting and often discussed candidate for sensing and conduction of $\mu g$ is the cellular cytoskeleton [30-33]. For this reason, we focused here on important cytoskeletal factors, associated focal adhesion complex molecules, and actin-binding proteins, which are all interconnected at the protein level (Figure 2). 
The actin cytoskeleton network is one of the most intensively investigated structures in $\mu g$. It is involved in cell shape, migration and stress response, among others [34]. In previous studies we found that the $\beta$-actin expression in TC cells as well as in other cell types is remarkably regulated during short- and long-term exposure to s- $\mu g$ and $r-\mu g[8,11,23,27]$. Following short-term $r-\mu g$ the ACTB gene expression was upregulated in a matter of seconds, for example [27]. These findings were emphasized by live-cell imaging during a sounding rocket flight, where F-actin cytoskeleton re-arrangements were monitored immediately after entering the $\mu g$-phase [12]. Here, we investigated FTC-133 follicular TC cells exposed to a 6-min RPM-exposure and found similar changes which support the findings from the previous rocket mission TX52.

During the TEXUS mission, the ACTB gene expression was constant in all controls as well as after $1 \mathrm{~min}$ of hyper- $g$, either on the rocket or in the control-experiment [20]. However, the $\mu g$-samples presented a distinct downregulation of $A C T B$, which is in line with findings from short-term experiments during a parabolic flight mission [12]. In contrast, after 7-day and 14-day-exposure of FTC-133 cells on the RPM, ACTB was found to be highly upregulated [8]. This indicates a strong regulatory effect on the cells as they start to form $3 \mathrm{D}$ cell aggregates [8].

Ezrin (EZR) and moesin (MSN) are part of a focal adhesion complex and interconnect the plasma membrane to the cytoskeleton [35]. Moesin forms a complex with ezrin and is able to bind to actin [36,37]. These proteins are strikingly involved in the surface structure adhesion, migration and have been associated with some human cancers $[38,39]$. Ezrin and moesin have also been found to be modulated in previous $\mu g$-experiments with thyroid cells $[12,28]$. During a $24 \mathrm{~h}$-exposure study on the RPM with the thyroid cancer cell line UCLA RO82-W-1, the EZR gene expression was significantly downregulated [28]. That is in alignment with the findings from the TEXUS flight, as only the expression in $\mu g$-samples was downregulated while controls and hyper- $g$ probes were not affected [20] and corresponds to the reduction of ezrin protein during 6 min on the RPM (Figure 4D). Interestingly, the MSN gene expression was slightly downregulated in $\mu g$-samples and upregulated in hyper- $g$ experiments. MSN was not found to be modulated during parabolic flights using microarray analyses [27]. However, a $24 \mathrm{~h}$ exposure on the RPM presented a downregulation in adherently growing cells, comparable to the present study [28].

\subsection{Real Microgravity Changes the Extracellular Matrix}

Furthermore, we investigated the ECM with a focus on fibronectin. Earlier detailed proteomic analyses have shown that FTC-133 cells express surface proteins that bind fibronectin, strengthening $3 \mathrm{D}$ growth [40]. These results are in agreement with our current data. We observed upregulated FN1 mRNA in $r-\mu g$ samples. In a former study, ML1 follicular TC cells were exposed to parabolic flight conditions. It was demonstrated that the COL4A5 mRNA was downregulated under r- $\mu g$, whereas $O P N$ and FN1 were significantly upregulated after 31 parabolas [27]. After six min $\mathrm{r}-\mu g$ the SPP1 gene expression was clearly elevated in $\mathrm{r}-\mu \mathrm{g}$ samples (Figure $3 \mathrm{H}$ ), but the COL4A5 mRNA kept a stable expression during the TEXUS flight (Figure $3 \mathrm{~F}$ ), indicating that the duration of $\mu g$ exposure might play a role in the upregulation of this basement membrane gene. In addition, ML1 TC cells exposed to the RPM revealed an increased synthesis of collagen type I and III, fibronectin, laminin and chondroitin sulfate [41].

Lysyl oxidase (LOX; protein-lysine 6-oxidase), is a protein that is encoded by the LOX gene. LOX upregulation in cancer cells is of importance in tumorigenesis and may promote progression of the primary tumor. qPCR analysis displayed a LOX upregulation in the TEXUS $r-\mu g$ group compared to all other groups (Figure 3R), the findings were confirmed by microarray technology. The LOX enzyme supports the cross-linking of collagen and elastin, which are both ECM components [42] and LOX gene expression was identified as promoting culture flask adherence of EA.hy926 cells [25]. During the Sino/German Simbox/Shenzhou-8 spaceflight mission, where the ECM linker LOX was virtually switched off, very large multicellular spheroids were formed [43]. 
The collagen homeostasis is maintained via collagen synthesis and degradation by the TC cells and is influenced by matrix metalloproteinases (MMPs). The MMPs themselves are regulated by TIMPs [44]. Little is known about matrix metalloproteinases and follicular TC. TIMP-1 was identified as a biomarker candidate for papillary TC [45]. Recently, the TIMP-1 secretion of space-flown FTC-133 cells was measured as 2.8-fold elevated. In parallel, the MMP-3 release was 5.94-fold elevated in ISS space samples compared to $1 g$-samples [46]. These results contradict earlier results. Following the SimBox/Shenzhou-8 space mission we detected a reduced MMP-3 secretion in both, RPM-samples and in space-flown samples [11]. The ECM plays a key role in tissue maintenance and integrity [47]. MMPs degrade the ECM and are involved in cancer progression and MMP activity is regulated by TIMPs [48]. The mode of action of TIMPs in cancer is yet not known, but there are reports about tumor suppression and tumor progression properties [49]. Here we found an increase in TIMP1, MMP1, $M M P 3$ and MMP14 mRNA expression in r- $\mu g$-samples (Figure $3 \mathrm{~K}-\mathrm{N}$ ), indicating an activation in orbit. These results support the data obtained from the ISS spaceflight in 2014 [46].

We detected an upregulation of the TGFB1 gene expression in the r- $\mu g$ group as compared to $1 g$-control cells (Figure 3J). No change was found after centrifugation. TGF- $\beta_{1}$ is a growth factor and a multifunctional cytokine. It is involved in biological processes like cell proliferation, adhesion and differentiation, and is therefore, a target in cancer therapy [50].

\subsection{Alteration of Focal Adhesion Proteins}

Focal adhesions or cell-matrix adhesions mediate cell signaling in response to ECM adhesion and serve as mechanical linkages to the ECM. Focal adhesions are known to be important gravisensors [51,52]. To determine alterations in focal adhesion proteins, we focused on vinculin as a first point of interest. Vinculin has a vital role in mechanotransduction with integrins at focal adhesion sites [53]. Vinculin also directly interacts with talin, integrins and actin, hence allowing a proper cellular migration and orchestrating focal adhesion [54]. In addition, vinculin is a component of the adherence junctions and mediates cellular and extracellular signals. The $V C L$ gene expression was not altered by $\mu g$, but elevated by centrifugation (Figure $4 \mathrm{H}$ ). Structure and morphology of vinculin was visualized by IFS (Figure $4 \mathrm{~F}, \mathrm{G}$ ). Interesting changes were visible by RPM-exposure (Figure 4G). Vinculin was disarranged in $\mathrm{s}-\mu g$, indicating a clear reaction to the low-gravity condition.

Another important focal adhesion factor is the cytosolic and mechanosensitive protein talin-1 (TLN1). It links integrin directly and indirectly via vinculin to the cytoskeleton. Integrins bind to talin and talin binds to vinculin and thus influence cell adhesion. In addition, the integrin receptors are involved in the attachment of adherent cells to the ECM. Talin is a mechanosensitive protein and is connecting integrins and the actin-cytoskeleton. It links actin to the integrin- $\beta_{1}$, which is inserted in the plasma membrane [55]. It is especially enriched in regions of cell-cell contacts and adhesion to substrate [56]. Because of its function, it is of high interest when cells transit from a two-dimensional (2D) cell growth to a 3D cell growth in $\mu g$. These 3D-aggregates or multicellular spheroids resemble the in vivo situation much closer than conventional cell cultures, making them extremely valuable for cancer research [6,57]. A downregulation of TLN1 in the early state of $\mu g$ might be an indication for detachment of the cells from the substrate [20]. On the background that talin has a vinculin-binding site and can recruit vinculin, it forms a complex with integrins and is thus inducing cell adhesion.

Integrin- $\beta_{1}$ (ITGB1) is a subunit of a plasma membrane associate receptor family which primarily detects ECM components [58]. It is bound to and activated by talin [59]. ITGB1 was not regulated in any experimental condition [20]. This is in in alignment with findings from short-term $\mu g$-experiments conducted during parabolic flight missions as ITGB1 was not regulated as well [27]. Interestingly, ITGB1 was regulated when human Nthy-ori-3-1 cells were exposed to a RPM for $24 \mathrm{~h}$ suggesting that the regulation is cell type-, time- or $\mu g$-origin-dependent [29].

In a next step, we focused on E-cadherin. Cadherins are $\mathrm{Ca}^{2+}$-dependent cell adhesion molecules in the cell-cell adherence junction, which belongs to the plasma membrane and is connected to cytoskeletal actin filaments [60]. E-cadherin's intracellular domains are connected to the cytoskeleton 
and its stability is regulated by catenin D1 [61], which can affect cell-cell adhesion [62]. E-cadherin is downregulated in tumors and multicellular MCF-7 breast cancer spheroids engineered by a 14-day RPM exposure and are known to be involved in metastasis [63]. The loss of E-cadherin expression in association with the epithelial-mesenchymal transition occurs frequently during tumor metastasis. The regulation of the adhesive activity of E-cadherin present at the cell surface by an inside-out signaling mechanism is important in cancer [64]. In this experiment, we found a slight increase in CDH1 mRNA in the r- $\mu g$ group, but no changes in all other groups (Figure $4 \mathrm{~J}$ ). This is an interesting finding because the E-cadherin ( $C D H 1)$ expression in cancer cells exposed to $r-\mu g$ is an unknown area. Proteomic pathway analyses demonstrated changes in papillary TC which were associated with the disruption of cell contacts (loss of E-cadherin), actin cytoskeleton dynamics and loss of differentiation markers, all hallmarks of an invasive phenotype [65].

We focused on the actin-binding protein cofilin, which disassembles actin filaments and influences the actin dynamics [66]. We determined the CFL1 gene expression and found an elevation in the r- $\mu g$ group compared with the respective controls (Figure $4 \mathrm{~K}$ ). In addition, the gene was upregulated by $18 g$-centrifugation, while the protein concentration was reduced after 6 min on the RPM (Figure 4L). Little is known concerning the impact of cofilin in follicular TC. An interesting proteomic analysis was published recently [66]. The authors investigated the fine needle aspiration fluid protein patterns of papillary thyroid carcinomas. A statistically significant upregulation of cofilin-1 was detected among others [67]. Cofilin-1 is determining the direction of cell migration and has importance for metastasis in papillary thyroid cancer [68]. Future experiments will be necessary to study cofilin-1 in follicular thyroid cancer in detail.

Furthermore, we studied focal adhesion kinase 1 (protein tyrosine kinase 2, PTK2), which plays an important part during cell migration. Interestingly, FAK1/PTK2 gene expression did not change by the sounding rocket flight, but it was upregulated by centrifugation. Recently, we showed that FTC-133 cells growing in monolayers or in spheroids after RPM-exposure incorporate vinculin, paxillin, focal adhesion kinase 1, and adenine diphosphate (ADP)-ribosylation factor 6 in different ways into the focal adhesion complex [69].

In summary, we were able show that focal adhesion proteins are important gravi-sensors and link the information to the ECM and the cytoskeleton.

In addition, we investigated the cell adhesion molecules ICAM-1 and VCAM-1. We had learned from the ISS CellBox-1 space mission that VCAM-1, TIMP1, protein kinase $C_{\alpha}$ and others are involved in the inhibition of spheroid formation under $r-\mu g$ [46]. Interestingly, both ICAM1 and VCAM1 mRNA expressions were slightly elevated in $\mathrm{r}-\mu g$-samples. They were not significantly altered after $18 g$-centrifugation or RPM-exposure. This finding might be due to the short $\mu g$-exposure time.

\subsection{Impact of altered gravity on cytokines}

Centrifugation with $18 \mathrm{~g}$ hyper- $g$ and simulating the 31 parabolas of a parabolic flight induced the gene expression of IL6 and CXCL8 in ML1 TC cells [26]. Here, we found a similar result. Short-term $18 g$-centrifugation upregulated both IL6 and CXCL8 mRNAs. In addition, there was an increase detectable in both genes in the r- $\mu$ g group. These results confirmed earlier data, when TC cells were exposed to the RPM. We did observe that the IL6 gene expression was enhanced in FTC-133 thyroid cancer cells, which remained adherent for $24 \mathrm{~h}$ on the RPM [23]. Similar results were obtained when human follicular epithelial thyroid Nthy-ori 3-1 cells were incubated for up to $72 \mathrm{~h}$ on the RPM [9]. Both cytokines have shown to have a 3D growth-promoting effect on follicular cancer spheroids [24]. In summary, the cytokines IL-6 and IL-8 are involved in migration and growth in thyroid cancer, and both are sensitive to altered gravity conditions. They seem to be involved in the initiation of MCS formation via focal adhesion proteins of benign cells [9] and cancer cells.

Taken together, our findings suggest that $\mu g$ is a much stronger trigger for gene expression changes than hyper- $g$. This enables us to adjust some controls in favor of $\mu g$-samples in future space missions, which will result in increased scientific output and saves resources. 


\section{Materials and Methods}

\subsection{Cell Cultures}

Cell culture and preparation of the experiments were performed as previously described in detail [20]. In short, FTC-133 poorly differentiated follicular thyroid cancer cells (Sigma Aldrich, St. Louis, MO, USA) were seeded into cell culture chambers at a defined density of $10^{6}$ cells $/$ chamber one day prior to the rocket launch (Figure 5A). These cell culture chambers were placed into late access unites, which ensured introduction into the rocket very close to launch (Figure 5B). During flight the cells were exposed to a variety of stressors, besides an on-flight $1 g$-centrifuge (Figure 5C). To discriminate between effects of $\mu g$ and the different stressors the cell culture chambers were fled with RNAlater (Thermofisher Scientific, Waltham, MA, USA) fixative at defined time points (Figure 5D), resulting in samples to be analyzed for gene expression changes back in the home laboratory. Furthermore, FTC-133 cells were exposed to worst case-hyper- $g$ on a centrifuge for $1 \mathrm{~min}$ which could have been the case during sounding rocket launch [20].
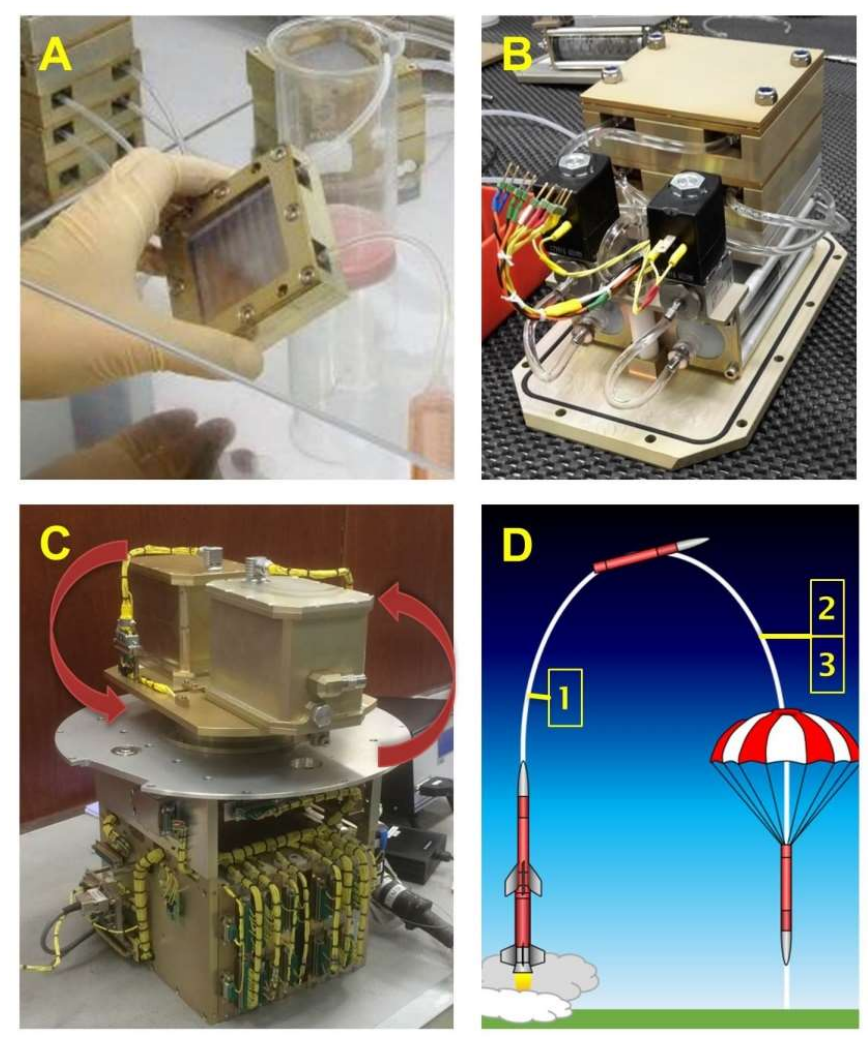

Figure 5. Workflow during the TEXUS-53 mission. Cell culture chamber were filled with cells (A) and afterwards placed into the late access unite (B). During flight a $1 g$-centrifuge (C) served as one control besides others. Red arrows indicate the rotation direction of the centrifuge. The cells were fixed at defined time points 1, 2, $3(\mathbf{D})$.

\subsection{TEXUS Sounding Rocket Mission}

Investigated conditions ranged from different $1 g$-controls, to hyper- $g$ - and $\mu g$-samples as described before [20]. In short, during a sounding rocket flight the launch phase of $1 \mathrm{~min}$ can reach an acceleration of up to $12 g$ which could have an effect on the cells (sample: TX53 Hyper- $g$ ). After the launch, the payload enters a 6 min $\mu g$-phase during which one part of the samples are kept on a $1 g$-centrifuge (sample: In-flight $1 g$-centrifuge), as a control, while the other part is exposed to $\mu g$ (sample: TX53 $\mu g$ ). Shortly before re-entering the Earth atmosphere samples are fixed as described before. In addition to the flight samples, on ground $1 g$ controls were performed with the cells kept horizontal (sample: TX53 
Ground Control) and vertical (sample: TX53 In-flight $1 g$ sim.). The vertical control was done due to the special arrangement of the cells on the in-flight centrifuge. Finally, a worst-case hyper-g experiment was performed keeping the cells on a centrifuge with $18 \mathrm{~g}$ for $1 \mathrm{~min}$ (sample: Hyper-g $1 \mathrm{~min}$ ).

\subsection{Random Positioning Machine}

Simulated $\mu g$ (s- $\mu g$ ) was performed on the desktop RPM (Airbus Defence and Space (ADS), Leiden, The Netherlands) located in a standard incubator $\left(37^{\circ} \mathrm{C}\right.$ and $\left.5 \% \mathrm{CO}_{2}\right)$ as previously described [70].

In brief, the RPM was operated in real random mode with random interval and direction with a maximum speed of 12.5 revolutions per minute. In each case sample flasks were placed onto the middle frame with a maximum distance of $7 \mathrm{~cm}$ to the center of rotation providing a $\mu g$ quality in the range of $10^{-4}-10^{-2} g(n=5$ samples each group/run) [10,71]. Samples were run on the RPM for $6 \mathrm{~min}$ to mimic the $\mu g$-phase of the sounding rocket flight. The RPM-samples and the corresponding static $1 g$-control flasks were completely filled with medium. The $1 g$-samples were placed in the incubator next to the RPM ( $n=5$ samples each group/run).

\subsection{F-actin Staining}

F-actin was visualized by means of rhodamine-phalloidin staining (Molecular Probes ${ }^{\circledR}$, Eugene, OR, USA). The nuclei were stained with Hoechst 33342 (Molecular Probes ${ }^{\circledR}$ ). The method was published earlier [72,73].

\subsection{Confocal Laser Scanning Microscopy (CLSM)}

The stained samples were examined using a confocal laser scanning microscope (LSM 780, Zeiss, Jena, Germany) using $40 \times$ oil-immersion objective with a NA of 1.3 [74].

\subsection{Immunofluorescence of Fibronectin, Vinculin and ICAM-1}

Immunofluorescence staining was performed to visualize changes in fibronectin, vinculin and ICAM-1 proteins. After the experiments, the cells were washed three times with PBS and afterwards fixed in $4 \%$ PFA (Sigma-Aldrich) for $30 \mathrm{~min}$ at room temperature. The primary antibodies (fibronectin, (Invitrogen, Carlsbad, CA, USA), mouse, dilution 1:100, vinculin (Abcam, Cambridge, UK), mouse, dilution 1:200, ICAM1, (Cell Signaling Technology, Danvers, MA, USA), rabbit, dilution 1:200) were applied for $24 \mathrm{~h}$. Then the slides were washed three times with PBS before incubation with secondary antibodies (AF488 conjugated anti-mouse/rabbit: 1:500, both Cell Signaling Technology) for $2 \mathrm{~h}$. Nuclei were stained with DAPI (4',6-diamidino-2-phenylindole) (Invitrogen) and mounted with Vectashield. Afterwards the slides were investigated by CLSM (LSM 780, Zeiss, Jena, Germany).

\subsection{Western Blot Analysis}

Western blotting was performed as described earlier [72,73]. In each experiment (performed three times) five different culture flasks were subjected to either s- $\mu g$ or $1 g$. At the end of the experiment cells were collected and solubilized in lysis buffer. Following lysis and centrifugation, aliquots of $30 \mu g$ were subjected to SDS-PAGE and Western blotting. For the RPM-samples five lanes representing the $\mathrm{AD}$ cells and five lanes representing $\mathrm{AD}$ static $1 g$-control cells were loaded. The samples were loaded on Criterion XT 4-12\% precast gels (BioRad, Hercules, CA, USA) and run for $1 \mathrm{~h}$ at 150 volts. Proteins were then transfer with a TurboBlot (Biorad) (100 V, $30 \mathrm{~min}$ ) to a PVDF membrane. Glycerine aldehyde-3-phosphate-dehydrogenase (GAPDH) was used as a loading control.

Membranes were then blocked $2 \mathrm{~h}$ in TBS-T containing 0.3\% I-Block (Applied Biosystems, Foster City, CA, USA). For detection of the selected antigens (see Table 2) the membranes were incubated overnight at room temperature in TBS-T and $0.3 \%$ I-Block solutions of the antibodies. Following three washing steps of $5 \mathrm{~min}$ membranes were incubated additionally $2 \mathrm{~h}$ at room temperature secondary with a Horseradish peroxidase (HRP)-linked antibody (Cell Signaling Technology Inc., Danvers, MA, 
USA) diluted 1:4000 in TBS-T and 0.3\% I-Block. The respective protein bands were visualized using BioRad Clarity Western ECL (BioRad) and images were captured with Image Quant LAS 4000 mini (GE Healthcare Life Science, Freiburg, Germany). Images of stained membranes were captured on Syngene PXi 4EZ image analysis system (Synoptics, Cambridge, UK) and analyzed using the ImageJ software (U.S. National Institutes of Health, Bethesda, MD, USA; http://rsb.info.nih.gov/ij/) for densitometric quantification of the respective bands and total protein load.

Table 2. Antibodies for Western blot analyses.

\begin{tabular}{ccccc}
\hline Antibodies & Company/No & Species & MW (kDa) & Dilution \\
\hline Collagen type I & Sigma/C2456 & $\mathrm{Ms}$ & $\sim 130$ & $1: 500$ \\
B-actin & Sigma/A5316 & $\mathrm{Ms}$ & 42 & $1: 2000$ \\
Fibronectin & Invitrogen/MA1198 & $\mathrm{Ms}$ & 250 & $1: 1000$ \\
Osteopontin & Sigma/07264 & $\mathrm{Rb}$ & 50 & $1: 1000$ \\
Cofilin & \#ab 42824 & $\mathrm{Rb}$ & 20 & $1: 2000$ \\
IL-8 & Abcam/ab7747 & $\mathrm{Rb}$ & 11 & $1: 500$ \\
Collagen type IV & Abcam/ab52235 & $\mathrm{Rb}$ & 160 & $1: 1000$ \\
Ezrin & Cell Signaling \#3145 & $\mathrm{Rb}$ & 81 & $1: 500$ \\
Moesin & Cell Signaling\#3150 & $\mathrm{Rb}$ & 78 & $1: 500$ \\
Vinculin & Abcam/ab18058 & $\mathrm{Ms}$ & 124 & $1: 1000$ \\
ICAM 1 & Cell Signaling \#4915S & $\mathrm{Rb}$ & $89-92$ & $1: 500$ \\
GAPDH & Abcam/ab9384 & $\mathrm{Rb}$ & 37 & $1: 1000$ \\
\hline
\end{tabular}

\subsection{Postflight $q P C R$ Analysis}

qPCR analysis was performed as previously described [42]. In short, samples from the mission were transported and stored in RNAlater. In addition, samples from hyper-g experiments were investigated. RNA was isolated from cells using the RNAeasy kit (Qiagen, Venlo, The Netherlands) following the manufactures instructions. After concentration determination via Nanodrop 2000, cDNA was produced using the first strand cDNA kit (Thermo Scientific, Waltham, MA, USA). qPCR was performed using the FAST SYBR ${ }^{\circledR}$ Select Master Mix (Applied Biosystem) and the 7500 Fast Real-Time PCR System (Applied Biosystems) to determine the expression levels of the target genes (Table 3). The selected primers were designed to span exon-exon junctions and to have a Tm of $60{ }^{\circ} \mathrm{C}$ using NCBI Primer Blast and were synthesized by TIB Molbiol (Berlin, Germany). Samples were normalized to $18 \mathrm{~S}$ rRNA and measured in triplicates. We used the comparative threshold cycle $\left(\Delta \Delta C_{\mathrm{T}}\right)$ method for relative quantification of transcription levels, with "TX53 Ground Control" set as 100\%.

\subsection{In-silico Analyses}

In-silico analyses were performed as described by Bauer et al. [22]. To investigate the mutual interactions of detected proteins, the UniProt accession numbers of the selected targets were induced in a Pathway Studio v.11 software (Elsevier Research Solutions, Amsterdam, The Netherlands) [63,69].

\subsection{Microarray Analysis}

Microarray analyses were performed as described by Kopp et al. [20].

\subsection{Statistics}

Statistical evaluation was performed using SPSS 15.0 (SPSS, Inc., Chicago, IL, USA). The Mann-Whitney-U-Test was used to compare the different conditions. All data is presented as mean \pm standard deviation (SD) with a significance level of * $p<0.05$. 
Table 3. Primer sequences for qPCR.

\begin{tabular}{|c|c|c|}
\hline Gene & Primer Name & Sequence \\
\hline \multirow{2}{*}{$18 S-r R N A$} & $18 S-F$ & GGAGCCTGCGGCTTAATTT \\
\hline & $18 S-\mathrm{R}$ & CAACTAAGAACGGCCATGCA \\
\hline \multirow{2}{*}{ AСТB } & ACTB-F & TGCCGACAGGATGCAGAAG \\
\hline & ACTB-R & GCCGATCCACACGGAGTACT \\
\hline \multirow{2}{*}{$\mathrm{CDH} 1$} & CDH1-F & GCTGGACCGAGAGAGTTTCC \\
\hline & CDH1-R & CAGCTGTTGCTGTTGTGCTT \\
\hline \multirow{2}{*}{$C F L$} & CFL-F & GAAGGAGGATCTGGTGTTTATCTTCT \\
\hline & CFL-R & CCTTGGAGCTGGCATAAATCAT \\
\hline \multirow{2}{*}{ COL1A1 } & COL1A1-F & ACGAAGACATCCCACCAATCAC \\
\hline & COL1A1-R & CGTTGTCGCAGACGCAGAT \\
\hline \multirow{2}{*}{ COL4A5 } & COL4A5-F & GGTACCTGTAACTACTATGCCAACTCCTA \\
\hline & COL4A5-R & CGGCTAATTCGTGTCCTCAAG \\
\hline \multirow{2}{*}{$E Z R$} & EZR-F & GCAATCCAGCCAAATACAACTG \\
\hline & EZR-R & CCACATAGTGGAGGCCAAAGTAC \\
\hline \multirow{2}{*}{ FAK1/PTK2 } & FAK1-F & TGTGGGTAAACCAGATCCTGC \\
\hline & FAK1-R & CTGAAGCTTGACACCCTCGT \\
\hline \multirow{2}{*}{ FN1 } & FN1-F & AGATCTACCTGTACACCTTGAATGACA \\
\hline & FN1-R & CATGATACCAGCAAGGAATTGG \\
\hline \multirow{2}{*}{ ICAM-1 } & ICAM1-F & CGGCTGACGTGTGCAGTAAT \\
\hline & ICAM1-R & CTTCTGAGACCTCTGGCTTCGT \\
\hline \multirow{2}{*}{ IL6 } & IL6-F & CGGGAACGAAAGAGAAGCTCTA \\
\hline & IL6-R & GAGCAGCCCCAGGGAGAA \\
\hline \multirow{2}{*}{ IL8/CXCL8 } & IL8-F & TGGCAGCCTTCCTGATTTCT \\
\hline & IL8-R & GGGTGGAAAGGTTTGGAGTATG \\
\hline \multirow{2}{*}{ ITGB1 } & ITGB1-F & GAAAACAGCGCATATCTGGAAATT \\
\hline & ITGB1-R & CAGCCAATCAGTGATCCACAA \\
\hline \multirow{2}{*}{ LOX } & LOX-F & TGGGAATGGCACAGTTGTCA \\
\hline & LOX-R & AGCCACTCTCCTCTGGGTGTT \\
\hline \multirow{2}{*}{$M M P 1$} & MMP1-F & GTCAGGGGAGATCATCGGG \\
\hline & MMP1-R & GAGCATCСССТССАATACСТG \\
\hline \multirow{2}{*}{ MMP3 } & MMP3-F & ACAAAGGATACAACAGGGACCAA \\
\hline & MMP3-R & TAGAGTGGGTACATCAAAGCTTCAGT \\
\hline \multirow{2}{*}{ MMP14 } & MMP14-F & ACTTTATGGGGGTGAGTCAGG \\
\hline & MMP14-R & GATGTTGGGCCCATAGGTGG \\
\hline \multirow{2}{*}{ MSN } & MSN-F & GAAATTTGTCATCAAGCCCATTG \\
\hline & MSN-R & CCATGCACAAGGCCAAGAT \\
\hline \multirow{2}{*}{ PFN1 } & PFN-F & GGGAATTTAGCATGGATCTTCGT \\
\hline & PFN-R & ACCGTGGACACCTTCTTTGC \\
\hline \multirow{2}{*}{ SSP1 } & SSP1-F & CGAGGTGATAGTGTGGTTTATGGA \\
\hline & SSP1-R & CGTCTGTAGCATCAGGGTACTG \\
\hline \multirow{2}{*}{ TGFB1 } & TGFB1-F & CACCCGCGTGCTAATGGT \\
\hline & TGFB1-R & AGAGCAACACGGGTTCAGGTA \\
\hline \multirow{2}{*}{ TIMP1 } & TIMP1-F & GCCATCGCCGCAGATC \\
\hline & TIMP1-R & GCTATCAGCCACAGCAACAACA \\
\hline & TLN1-F & GATGGCTATTACTCAGTACAGACAACTGA \\
\hline TLN1 & TLN1-R & CATAGTAGACTCСТСАТСТССТTССА \\
\hline $\mathrm{UCAM} 1$ & VCAM1-F & CATGGAATTCGAACCCAAACA \\
\hline VCAM-1 & VCAM1-R & GGCTGACCAAGACGGTTGTATC \\
\hline & VCL-F & GTCTCGGCTGCTCGTATCTT \\
\hline$V C L$ & VCL-R & GTCCACCAGCCCTGTCATTT \\
\hline
\end{tabular}




\section{Conclusions}

Taken together, simulated hyper-g induced the gene expression of COL1A1, VCL, CFL1, PTK2, IL6, CXCL8 and MMP14.

Unfortunately, after the TX53 mission, we noticed that only two $r-\mu g$ samples were fixed with RNAlater [20], so that no statistical evaluation was possible. qPCR measured elevated mRNA of the ECM genes FN1, SPP1, TGFB1, TIMP1, MMP1, MMP3, MMP14. In addition, the cell adhesion genes ICAM1 and VCAM1, the focal adhesion factors CFL1 and CDH1 as well as cytokines IL6 and CXCL8 were upregulated in $\mathrm{r}-\mu \mathrm{g}$ samples. All these factors have demonstrated their gravi-sensitivity. FN1 and TIMP1 are recently proposed as potential target genes in papillary TC [75]. Downregulation of E-cadherin plays a role in metastasis, and the restoration of E-cadherin inhibits tumor growth. Antibodies reducing E-cadherin activity favor MCS formation, and PP2, blocking the E-cadherin reducer SRC prevents MCS formation in vitro [63]. Therefore, E-cadherin seems to be an interesting target in follicular TC. Future detailed investigations focusing on E-cadherin/ $\beta$-catenin signaling will be performed.

Furthermore, we were able to show that $\mu g$ achieved by a sounding rocket flight is a strong trigger for gene expression changes in FTC-133 cells. Future studies during TEXUS sounding rocket missions will be performed in order to increase the number of samples.

Author Contributions: Sounding rocket flight, A.S., B.S., H.O., and S.F.; Conceptualization, D.G. and J.B.; methodology, S.K., M.Z.N., J.S., T.J.B., and D.M.; Software, H.S. and J.B.; Validation, D.G., T.J.C., S.K., M.K. and D.M.; Formal analysis, S.K., J.S., and M.W.; Investigation, S.K.; Resources, M.I.; Writing-Original draft preparation, S.K., T.J.C, M.K., D.G., J.B.; Project administration, D.G.; funding acquisition, D.G. and M.I.

Funding: This research was funded by the German Space Agency (DLR; BMWi project 50WB1524).

Acknowledgments: We like to thank Otfried Joop and Markus Braun (German Space Agency DLR, Bonn) for their support and for giving us the possibility to attend the TEXUS mission in Kiruna, Sweden. This paper was presented at the 69th International Astronautical Congress, 1-5 October 2018, Bremen, Germany. www.iafastro.org.

Conflicts of Interest: The authors declare no conflict of interest. The funders had no role in the design of the study; in the collection, analyses, or interpretation of data; in the writing of the manuscript, or in the decision to publish the results.

\section{Abbreviations}

$\begin{array}{ll}\mu g & \text { Microgravity } \\ \text { 2D } & \text { two-dimensional } \\ \text { 3D } & \text { three-dimensional } \\ \text { AD } & \text { adherently growing } \\ \text { ADS } & \text { Airbus Defence and Space } \\ \text { CDH1 } & \text { Cadherin-1/E-cadherin } \\ \text { CFL1 } & \text { Cofilin } \\ \text { COL1A1/COL4A5 } & \text { Collagen 1A1/Collagen 4A5 } \\ \text { CXCL8 } & \text { Interleukin 8 } \\ \text { ECM } & \text { Extracellular Matrix } \\ \text { ERM } & \text { Ezrin-Radixin-Moesin } \\ \text { FN1 } & \text { Fibronectin 1 } \\ \text { ICAM1 } & \text { Intercellular adhesion molecule 1 } \\ \text { IL6 } & \text { Interleukin 6 } \\ \text { IMS } & \text { Immunofluorescence staining } \\ \text { ITGB1 } & \text { Integrin beta-1 } \\ \text { LOX } & \text { Protein-lysine 6-oxidase } \\ \text { MCS } & \text { Multicellular spheroids } \\ \text { MMPs } & \text { Matrix metalloproteinases } \\ \text { PTK2/FAK1 } & \text { Focal adhesion kinase 1 } \\ \text { qPCR } & \text { Quantitative PCR } \\ \text { r- } & \text { real- }\end{array}$




$\begin{array}{ll}\text { RAI } & \text { Radioiodine therapy } \\ \text { RPM } & \text { Random Positioning Machine } \\ \text { s- } & \text { simulated- } \\ \text { SPP1 } & \text { Secreted Phosphoprotein 1 / Osteopontin } \\ \text { TC } & \text { Thyroid cancer } \\ \text { TGFB1 } & \text { Transforming growth factor beta-1 } \\ \text { TIMP1 } & \text { Metallopeptidase (proteinase) inhibitor 1 } \\ \text { TX } & \text { TEXUS } \\ \text { VCAM1 } & \text { Vascular cell adhesion protein 1 } \\ \text { ADM } & \text { Adrenomedullin } \\ \text { GJB2 } & \text { Gap junction beta-2 protein } \\ \text { PFKFB4 } & \text { 6-phosphofructo-2-kinase/fructose-2,6-biphospatase 4 } \\ \text { KISS1R } & \text { KiSS-1 receptor } \\ \text { NDRG1 } & \text { Protein NDRG1 } \\ \text { IGFBP3 } & \text { Insulin-like growth factor-binding protein 3 }\end{array}$

\section{References}

1. Bray, F.; Ferlay, J.; Soerjomataram, I.; Siegel, R.L.; Torre, L.A.; Jemal, A. Global cancer statistics 2018: Globocan estimates of incidence and mortality worldwide for 36 cancers in 185 countries. CA Cancer J. Clin. 2018, 68, 394-424. [CrossRef] [PubMed]

2. Ancker, O.V.; Wehland, M.; Bauer, J.; Infanger, M.; Grimm, D. The adverse effect of hypertension in the treatment of thyroid cancer with multi-kinase inhibitors. Int. J. Mol. Sci. 2017, 18, 625. [CrossRef] [PubMed]

3. Omur, O.; Baran, Y. An update on molecular biology of thyroid cancers. Crit. Rev. Oncol. Hematol. 2014, 90, 233-252. [CrossRef] [PubMed]

4. Laursen, R.; Wehland, M.; Kopp, S.; Pietsch, J.; Infanger, M.; Grosse, J.; Grimm, D. Effects and role of multikinase inhibitors in thyroid cancer. Curr. Pharm. Des. 2016, 22, 5915-5926. [CrossRef] [PubMed]

5. Grimm, D.; Egli, M.; Kruger, M.; Riwaldt, S.; Corydon, T.J.; Kopp, S.; Wehland, M.; Wise, P.; Infanger, M.; Mann, V.; et al. Tissue engineering under microgravity conditions-use of stem cells and specialized cells. Stem Cells Dev. 2018, 27, 787-804. [CrossRef] [PubMed]

6. Grimm, D.; Wehland, M.; Pietsch, J.; Aleshcheva, G.; Wise, P.; van Loon, J.; Ulbrich, C.; Magnusson, N.E.; Infanger, M.; Bauer, J. Growing tissues in real and simulated microgravity: New methods for tissue engineering. Tissue Eng. Part B Rev. 2014, 20, 555-566. [CrossRef] [PubMed]

7. Strauch, S.M.; Grimm, D.; Corydon, T.J.; Krüger, M.; Bauer, J.; Lebert, M.; Wise, P.; Infanger, M.; Richter, P. Current knowledge about the impact of microgravity on the proteome. Expert Rev. Proteom. 2018, 1-12. [CrossRef] [PubMed]

8. Kopp, S.; Warnke, E.; Wehland, M.; Aleshcheva, G.; Magnusson, N.E.; Hemmersbach, R.; Corydon, T.J.; Bauer, J.; Infanger, M.; Grimm, D. Mechanisms of three-dimensional growth of thyroid cells during long-term simulated microgravity. Sci. Rep. 2015, 5, 16691. [CrossRef] [PubMed]

9. Warnke, E.; Pietsch, J.; Kopp, S.; Bauer, J.; Sahana, J.; Wehland, M.; Krüger, M.; Hemmersbach, R.; Infanger, M.; Lützenberg, R.; et al. Cytokine release and focal adhesion proteins in normal thyroid cells cultured on the random positioning machine. Cell. Physiol. Biochem. 2017, 43, 257-270. [CrossRef] [PubMed]

10. Warnke, E.; Pietsch, J.; Wehland, M.; Bauer, J.; Infanger, M.; Görög, M.; Hemmersbach, R.; Braun, M.; Ma, X.; Sahana, J.; et al. Spheroid formation of human thyroid cancer cells under simulated microgravity: A possible role of CTGF and CAV1. Cell Commun. Signal. 2014, 12, 32. [CrossRef]

11. Ma, X.; Pietsch, J.; Wehland, M.; Schulz, H.; Saar, K.; Hübner, N.; Bauer, J.; Braun, M.; Schwarzwälder, A.; Segerer, J.; et al. Differential gene expression profile and altered cytokine secretion of thyroid cancer cells in space. FASEB J. 2014, 28, 813-835. [CrossRef] [PubMed]

12. Corydon, T.J.; Kopp, S.; Wehland, M.; Braun, M.; Schütte, A.; Mayer, T.; Hulsing, T.; Oltmann, H.; Schmitz, B.; Hemmersbach, R.; et al. Alterations of the cytoskeleton in human cells in space proved by life-cell imaging. Sci. Rep. 2016, 6, 20043. [CrossRef] [PubMed]

13. Ingber, D. How cells (might) sense microgravity. FASEB J. 1999, 13, S3-S15. [CrossRef] [PubMed] 
14. Ingber, D.E.; Wang, N.; Stamenovic, D. Tensegrity, cellular biophysics, and the mechanics of living systems. Rep. Prog. Phys. 2014, 77, 046603. [CrossRef] [PubMed]

15. Schoenwaelder, S.M.; Burridge, K. Bidirectional signaling between the cytoskeleton and integrins. Curr. Opin. Cell Biol. 1999, 11, 274-286. [CrossRef]

16. Yamada, K.M.; Geiger, B. Molecular interactions in cell adhesion complexes. Curr. Opin. Cell Biol. 1997, 9, 76-85. [CrossRef]

17. Calderwood, D.A.; Shattil, S.J.; Ginsberg, M.H. Integrins and actin filaments: Reciprocal regulation of cell adhesion and signaling. J. Biol. Chem. 2000, 275, 22607-22610. [CrossRef] [PubMed]

18. McClatchey, A.I. Erm proteins at a glance. J. Cell Sci. 2014, 127, 3199-3204. [CrossRef] [PubMed]

19. Schwartz, M.A. Integrins and extracellular matrix in mechanotransduction. Cold Spring Harb. Perspect. Biol. 2010, 2, a005066. [CrossRef]

20. Kopp, S.; Krüger, M.; Feldmann, S.; Oltmann, H.; Schütte, A.; Schmitz, B.; Bauer, J.; Schulz, H.; Saar, K.; Huebner, N.; et al. Thyroid cancer cells in space during the texus- 53 sounding rocket mission-The thyroid project. Sci. Rep. 2018, 8, 10355. [CrossRef]

21. Bauer, J.; Grimm, D.; Gombocz, E. Semantic analysis of thyroid cancer cell proteins obtained from rare research opportunities. J. Biomed. Inform. 2017, 76, 138-153. [CrossRef] [PubMed]

22. Bauer, J.; Wehland, M.; Infanger, M.; Grimm, D.; Gombocz, E. Semantic analysis of posttranslational modification of proteins accumulated in thyroid cancer cells exposed to simulated microgravity. Int. J. Mol. Sci. 2018, 19, 2257. [CrossRef] [PubMed]

23. Grosse, J.; Wehland, M.; Pietsch, J.; Schulz, H.; Saar, K.; Hubner, N.; Eilles, C.; Bauer, J.; Abou-El-Ardat, K.; Baatout, S.; et al. Gravity-sensitive signaling drives 3-dimensional formation of multicellular thyroid cancer spheroids. FASEB J. 2012, 26, 5124-5140. [CrossRef] [PubMed]

24. Svejgaard, B.; Wehland, M.; Ma, X.; Kopp, S.; Sahana, J.; Warnke, E.; Aleshcheva, G.; Hemmersbach, R.; Hauslage, J.; Grosse, J.; et al. Common effects on cancer cells exerted by a random positioning machine and a 2d clinostat. PLoS ONE 2015, 10, e0135157. [CrossRef] [PubMed]

25. Ma, X.; Wehland, M.; Schulz, H.; Saar, K.; Hübner, N.; Infanger, M.; Bauer, J.; Grimm, D. Genomic approach to identify factors that drive the formation of three-dimensional structures by ea.Hy926 endothelial cells. PLOS ONE 2013, 8, e64402. [CrossRef]

26. Ma, X.; Wehland, M.; Aleshcheva, G.; Hauslage, J.; Wasser, K.; Hemmersbach, R.; Infanger, M.; Bauer, J.; Grimm, D. Interleukin-6 expression under gravitational stress due to vibration and hypergravity in follicular thyroid cancer cells. PLoS ONE 2013, 8, e68140. [CrossRef]

27. Ulbrich, C.; Pietsch, J.; Grosse, J.; Wehland, M.; Schulz, H.; Saar, K.; Hubner, N.; Hauslage, J.; Hemmersbach, R.; Braun, M.; et al. Differential gene regulation under altered gravity conditions in follicular thyroid cancer cells: Relationship between the extracellular matrix and the cytoskeleton. Cell. Physiol. Biochem. 2011, 28, 185-198. [CrossRef]

28. Riwaldt, S.; Bauer, J.; Wehland, M.; Slumstrup, L.; Kopp, S.; Warnke, E.; Dittrich, A.; Magnusson, N.E.; Pietsch, J.; Corydon, T.J.; et al. Pathways regulating spheroid formation of human follicular thyroid cancer cells under simulated microgravity conditions: A genetic approach. Int. J. Mol. Sci. 2016, 17, 528. [CrossRef]

29. Warnke, E.; Kopp, S.; Wehland, M.; Hemmersbach, R.; Bauer, J.; Pietsch, J.; Infanger, M.; Grimm, D. Thyroid cells exposed to simulated microgravity conditions-Comparison of the fast rotating clinostat and the random positioning machine. Microgravity Sci. Technol. 2016, 28, 247-260. [CrossRef]

30. Buravkova, L.B.; Romanov, Y.A. The role of cytoskeleton in cell changes under condition of simulated microgravity. Acta Astronaut. 2001, 48, 647-650. [CrossRef]

31. Crawford-Young, S.J. Effects of microgravity on cell cytoskeleton and embryogenesis. Int. J. Dev. Biol. 2006, 50, 183-191. [CrossRef] [PubMed]

32. Hughes-Fulford, M. Function of the cytoskeleton in gravisensing during spaceflight. Adv. Space Res. 2003, 32, 1585-1593. [CrossRef]

33. Vorselen, D.; Roos, W.H.; MacKintosh, F.C.; Wuite, G.J.; van Loon, J.J. The role of the cytoskeleton in sensing changes in gravity by nonspecialized cells. FASEB J. 2014, 28, 536-547. [CrossRef] [PubMed]

34. Huber, F.; Schnauss, J.; Ronicke, S.; Rauch, P.; Muller, K.; Futterer, C.; Kas, J. Emergent complexity of the cytoskeleton: From single filaments to tissue. Adv. Phys. 2013, 62, 1-112. [CrossRef] [PubMed]

35. Tsukita, S.; Yonemura, S.; Tsukita, S. Erm proteins: Head-to-tail regulation of actin-plasma membrane interaction. Trends Biochem. Sci. 1997, 22, 53-58. [CrossRef] 
36. Neisch, A.L.; Fehon, R.G. Ezrin, radixin and moesin: Key regulators of membrane-cortex interactions and signaling. Curr. Opin. Cell Biol. 2011, 23, 377-382. [CrossRef]

37. Pearson, M.A.; Reczek, D.; Bretscher, A.; Karplus, P.A. Structure of the erm protein moesin reveals the ferm domain fold masked by an extended actin binding tail domain. Cell 2000, 101, 259-270. [CrossRef]

38. Barros, F.B.A.; Assao, A.; Garcia, N.G.; Nonogaki, S.; Carvalho, A.L.; Soares, F.A.; Kowalski, L.P.; Oliveira, D.T. Moesin expression by tumor cells is an unfavorable prognostic biomarker for oral cancer. BMC Cancer 2018, 18, 53. [CrossRef]

39. Bartova, M.; Hlavaty, J.; Tan, Y.; Singer, C.; Pohlodek, K.; Luha, J.; Walter, I. Expression of ezrin and moesin in primary breast carcinoma and matched lymph node metastases. Clin. Exp. Metastasis 2017, 34, 333-344. [CrossRef]

40. Pietsch, J.; Sickmann, A.; Weber, G.; Bauer, J.; Egli, M.; Wildgruber, R.; Infanger, M.; Grimm, D. A proteomic approach to analysing spheroid formation of two human thyroid cell lines cultured on a random positioning machine. Proteomics 2011, 11, 2095-2104. [CrossRef]

41. Grimm, D.; Bauer, J.; Kossmehl, P.; Shakibaei, M.; Schöberger, J.; Pickenhahn, H.; Schulze-Tanzil, G.; Vetter, R.; Eilles, C.; Paul, M.; et al. Simulated microgravity alters differentiation and increases apoptosis in human follicular thyroid carcinoma cells. FASEB J. 2002, 16, 604-606. [CrossRef] [PubMed]

42. Levene, C.I.; Carrington, M.J. The inhibition of protein-lysine 6-oxidase by various lathyrogens. Evidence for two different mechanisms. Biochem. J. 1985, 232, 293-296. [CrossRef] [PubMed]

43. Bauer, J.; Wehland, M.; Pietsch, J.; Sickmann, A.; Weber, G.; Grimm, D. Annotated gene and proteome data support recognition of interconnections between the results of different experiments in space research. Microgravity Sci. Technol. 2016, 28, 357-365. [CrossRef]

44. Arpino, V.; Brock, M.; Gill, S.E. The role of timps in regulation of extracellular matrix proteolysis. Matrix Biol. 2015, 44-46, 247-254. [CrossRef]

45. Hawthorn, L.; Stein, L.; Varma, R.; Wiseman, S.; Loree, T.; Tan, D. TIMP1 and SERPIN-A overexpression and TFF3 and CRABP1 underexpression as biomarkers for papillary thyroid carcinoma. Head Neck 2004, 26, 1069-1083. [CrossRef]

46. Riwaldt, S.; Bauer, J.; Pietsch, J.; Braun, M.; Segerer, J.; Schwarzwälder, A.; Corydon, T.J.; Infanger, M.; Grimm, D. The importance of caveolin-1 as key-regulator of three-dimensional growth in thyroid cancer cells cultured under real and simulated microgravity conditions. Int. J. Mol. Sci. 2015, 16, 28296-28310. [CrossRef]

47. Marastoni, S.; Ligresti, G.; Lorenzon, E.; Colombatti, A.; Mongiat, M. Extracellular matrix: A matter of life and death. Connect. Tissue Res. 2008, 49, 203-206. [CrossRef]

48. Chaudhary, A.K.; Pandya, S.; Ghosh, K.; Nadkarni, A. Matrix metalloproteinase and its drug targets therapy in solid and hematological malignancies: An overview. Mutat. Res. 2013, 753, 7-23. [CrossRef]

49. Kraiem, Z.; Korem, S. Matrix metalloproteinases and the thyroid. Thyroid 2000, 10, 1061-1069. [CrossRef]

50. Kingsley, D.M. The TGF- $\beta$ superfamily: New members, new receptors, and new genetic tests of function in different organisms. Genes Dev. 1994, 8, 133-146. [CrossRef]

51. Geiger, B.; Spatz, J.P.; Bershadsky, A.D. Environmental sensing through focal adhesions. Nat. Rev. Mol. Cell Biol. 2009, 10, 21-33. [CrossRef] [PubMed]

52. Zhao, T.; Li, R.; Tan, X.; Zhang, J.; Fan, C.; Zhao, Q.; Deng, Y.; Xu, A.; Lukong, K.E.; Genth, H.; et al. Simulated microgravity reduces focal adhesions and alters cytoskeleton and nuclear positioning leading to enhanced apoptosis via suppressing FAK/RhoA-mediated mTORC1/NF-кB and ERK1/2 pathways. Int. J. Mol. Sci. 2018, 19, 1994. [CrossRef] [PubMed]

53. Spanjaard, E.; de Rooij, J. Mechanotransduction: Vinculin provides stability when tension rises. Curr. Biol. 2013, 23, R159-R161. [CrossRef] [PubMed]

54. Humphries, J.D.; Wang, P.; Streuli, C.; Geiger, B.; Humphries, M.J.; Ballestrem, C. Vinculin controls focal adhesion formation by direct interactions with talin and actin. J. Cell Biol. 2007, 179, 1043-1057. [CrossRef] [PubMed]

55. Tadokoro, S.; Shattil, S.J.; Eto, K.; Tai, V.; Liddington, R.C.; de Pereda, J.M.; Ginsberg, M.H.; Calderwood, D.A. Talin binding to integrin $\beta$ tails: A final common step in integrin activation. Science 2003, 302, 103-106. [CrossRef] [PubMed]

56. Critchley, D.R. Biochemical and structural properties of the integrin-associated cytoskeletal protein talin. Annu. Rev. Biophys. 2009, 38, 235-254. [CrossRef] [PubMed] 
57. Aleshcheva, G.; Bauer, J.; Hemmersbach, R.; Slumstrup, L.; Wehland, M.; Infanger, M.; Grimm, D. Scaffold-free tissue formation under real and simulated microgravity conditions. Basic Clin. Pharmacol. Toxicol. 2016, 119 (Suppl. 3), 26-33. [CrossRef]

58. Goodfellow, P.J.; Nevanlinna, H.A.; Gorman, P.; Sheer, D.; Lam, G.; Goodfellow, P.N. Assignment of the gene encoding the $\beta$-subunit of the human fibronectin receptor ( $\beta$-FNR) to chromosome 10p11.2. Ann. Hum. Genet. 1989, 53, 15-22. [CrossRef]

59. Bouaouina, M.; Lad, Y.; Calderwood, D.A. The N-terminal domains of talin cooperate with the phosphotyrosine binding-like domain to activate $\beta 1$ and $\beta 3$ integrins. J. Biol. Chem. 2008, 283, 6118-6125. [CrossRef]

60. Van Roy, F.; Berx, G. The cell-cell adhesion molecule E-cadherin. Cell. Mol. Life Sci. 2008, 65, 3756-3788. [CrossRef]

61. Reynolds, A.B. P120-catenin: Past and present. Biochim. Biophys. Acta 2007, 1773, 2-7. [CrossRef] [PubMed]

62. Ishiyama, N.; Ikura, M. The three-dimensional structure of the cadherin-catenin complex. In Adherens Junctions: From Molecular Mechanisms to Tissue Development and Disease; Subcellular Biochemistry; Springer: Dordrecht, The Netherlands, 2012; Volume 60, pp. 39-62.

63. Sahana, J.; Nassef, M.Z.; Wehland, M.; Kopp, S.; Krüger, M.; Corydon, T.J.; Infanger, M.; Bauer, J.; Grimm, D. Decreased E-cadherin in MCF7 human breast cancer cells forming multicellular spheroids exposed to simulated microgravity. Proteomics 2018, 18, e1800015. [CrossRef] [PubMed]

64. Petrova, Y.I.; Schecterson, L.; Gumbiner, B.M. Roles for E-cadherin cell surface regulation in cancer. Mol. Biol. Cell 2016, 27, 3233-3244. [CrossRef] [PubMed]

65. Martinez-Aguilar, J.; Clifton-Bligh, R.; Molloy, M.P. Proteomics of thyroid tumours provides new insights into their molecular composition and changes associated with malignancy. Sci. Rep. 2016, 6, 23660. [CrossRef] [PubMed]

66. McGough, A.; Pope, B.; Chiu, W.; Weeds, A. Cofilin changes the twist of F-actin: Implications for actin filament dynamics and cellular function. J. Cell Biol. 1997, 138, 771-781. [CrossRef]

67. Giusti, L.; Iacconi, P.; Ciregia, F.; Giannaccini, G.; Donatini, G.L.; Basolo, F.; Miccoli, P.; Pinchera, A.; Lucacchini, A. Fine-needle aspiration of thyroid nodules: Proteomic analysis to identify cancer biomarkers. J. Proteome Res. 2008, 7, 4079-4088. [CrossRef]

68. Maimaiti, Y.; Jie, T.; Jing, Z.; Changwen, W.; Pan, Y.; Chen, C.; Tao, H. Aurora kinase a induces papillary thyroid cancer lymph node metastasis by promoting cofilin-1 activity. Biochem. Biophys. Res. Commun. 2016, 473, 212-218. [CrossRef]

69. Bauer, J.; Kopp, S.; Schlagberger, E.M.; Grosse, J.; Sahana, J.; Riwaldt, S.; Wehland, M.; Luetzenberg, R.; Infanger, M.; Grimm, D. Proteome analysis of human follicular thyroid cancer cells exposed to the random positioning machine. Int. J. Mol. Sci. 2017, 18, 546. [CrossRef]

70. Kopp, S.; Sahana, J.; Islam, T.; Petersen, A.G.; Bauer, J.; Corydon, T.J.; Schulz, H.; Saar, K.; Huebner, N.; Slumstrup, L.; et al. The role of NFKB in spheroid formation of human breast cancer cells cultured on the Random Positioning Machine. Sci. Rep. 2018, 8, 921. [CrossRef]

71. Wuest, S.L.; Richard, S.; Kopp, S.; Grimm, D.; Egli, M. Simulated microgravity: Critical review on the use of random positioning machines for mammalian cell culture. BioMed Res. Int. 2015, 2015, 971474. [CrossRef]

72. Aleshcheva, G.; Sahana, J.; Ma, X.; Hauslage, J.; Hemmersbach, R.; Egli, M.; Infanger, M.; Bauer, J.; Grimm, D. Changes in morphology, gene expression and protein content in chondrocytes cultured on a random positioning machine. PLoS ONE 2013, 8, e79057. [CrossRef] [PubMed]

73. Aleshcheva, G.; Wehland, M.; Sahana, J.; Bauer, J.; Corydon, T.J.; Hemmersbach, R.; Frett, T.; Egli, M.; Infanger, M.; Grosse, J.; et al. Moderate alterations of the cytoskeleton in human chondrocytes after short-term microgravity produced by parabolic flight maneuvers could be prevented by up-regulation of BMP-2 and SOX-9. FASEB J. 2015, 29, 2303-2314. [CrossRef] [PubMed]

74. Nyegaard, M.; Rendtorff, N.D.; Nielsen, M.S.; Corydon, T.J.; Demontis, D.; Starnawska, A.; Hedemand, A.; Buniello, A.; Niola, F.; Overgaard, M.T.; et al. A novel locus harbouring a functional CD164 nonsense mutation identified in a large danish family with nonsyndromic hearing impairment. PLoS Genet. 2015, 11, e1005386. [CrossRef] [PubMed]

75. Zhang, K.; Liu, J.; Li, C.; Peng, X.; Li, H.; Li, Z. Identification and validation of potential target genes in papillary thyroid cancer. Eur. J. Pharmacol. 2018, 843, 217-225. [CrossRef] [PubMed]

(C) 2018 by the authors. Licensee MDPI, Basel, Switzerland. This article is an open access article distributed under the terms and conditions of the Creative Commons Attribution (CC BY) license (http:/ / creativecommons.org/licenses/by/4.0/). 